\title{
Review \\ Candidate Genes for Eyelid Myoclonia with Absences, Review of the Literature
}

\author{
Sonia Mayo ${ }^{1, *,+} \mathbb{D}$, Irene Gómez-Manjón ${ }^{1,2,+} \mathbb{D}$, Fco. Javier Fernández-Martínez ${ }^{1,2,+}{ }^{\text {, Ana Camacho }}{ }^{3, \ddagger}$, \\ Francisco Martínez $4,5, \ddagger$ (iD) and Julián Benito-León $6,7,8, \ddagger$ (D)
}

1 Genetics and Inheritance Research Group, Instituto de Investigación Sanitaria Hospital 12 de Octubre (imas12), 28041 Madrid, Spain; irenegomezmanjon@hotmail.com (I.G.-M.); ffernandezm@salud.madrid.org (F.J.F.-M.)

2 Department of Genetics, Hospital Universitario 12 de Octubre, 28041 Madrid, Spain

3 Department of Neurology, Division of Pediatric Neurology, Hospital Universitario 12 de Octubre, Universidad Complutense de Madrid, 28041 Madrid, Spain; acamacho@salud.madrid.org

4 Traslational Research in Genetics, Instituto de Investigación Sanitaria La Fe (IIS La Fe), 46026 Valencia, Spain; martinez_fracas@gva.es

5 Genetics Unit, Hospital Universitario y Politecnico La Fe, 46026 Valencia, Spain

6 Department of Neurology, Hospital Universitario 12 de Octubre, 28041 Madrid, Spain; jbenitol67@gmail.com

7 Centro de Investigación Biomédica en Red sobre Enfermedades Neurodegenerativas (CIBERNED), 28031 Madrid, Spain

8 Department of Medicine, Universidad Complutense de Madrid, 28040 Madrid, Spain

* Correspondence: soniamayodeandres@gmail.com; Tel.: +34-91-779-2603

+ S.M., I.G.-M. and F.J.F.-M. contributed equally to this work and should be considered joint first authors.

‡ A.C., F.M. and J.B.-L. contributed equally to this work and should be considered joint senior authors.

Citation: Mayo, S.; Gómez-Manjón,

I.; Fernández-Martínez, F..J.;

Camacho, A.; Martínez, F.;

Benito-León, J. Candidate Genes for Eyelid Myoclonia with Absences,

Review of the Literature. Int. J. Mol.

Sci. 2021, 22, 5609. https://doi.org/ $10.3390 /$ ijms 22115609

Academic Editor: Elek Molnár

Received: 7 May 2021

Accepted: 21 May 2021

Published: 25 May 2021

Publisher's Note: MDPI stays neutral with regard to jurisdictional claims in published maps and institutional affiliations.

Copyright: (c) 2021 by the authors. Licensee MDPI, Basel, Switzerland. This article is an open access article distributed under the terms and conditions of the Creative Commons Attribution (CC BY) license (https:/ / creativecommons.org/licenses/by/ $4.0 /)$.

\begin{abstract}
Eyelid myoclonia with absences (EMA), also known as Jeavons syndrome (JS) is a childhood onset epileptic syndrome with manifestations involving a clinical triad of absence seizures with eyelid myoclonia (EM), photosensitivity (PS), and seizures or electroencephalogram (EEG) paroxysms induced by eye closure. Although a genetic contribution to this syndrome is likely and some genetic alterations have been defined in several cases, the genes responsible for have not been identified. In this review, patients diagnosed with EMA (or EMA-like phenotype) with a genetic diagnosis are summarized. Based on this, four genes could be associated to this syndrome (SYNGAP1, KIA02022/NEXMIF, RORB, and CHD2). Moreover, although there is not enough evidence yet to consider them as candidate for EMA, three more genes present also different alterations in some patients with clinical diagnosis of the disease (SLC2A1, NAA10, and KCNB1). Therefore, a possible relationship of these genes with the disease is discussed in this review.
\end{abstract}

Keywords: Jeavons syndrome; eyelid myoclonia with absences; candidate genes; SYNGAP1; KIA02022; NEXMIF; RORB; CHD2

\section{Introduction}

In 1977, Jeavons described something that is now known as Jeavons syndrome (JS): "Eyelid myoclonia and absences show a marked jerking of the eyelids immediately after eye closure and there is associated brief bilateral spike-and-wave activity. The eyelid movement is like rapid blinking and the eyes deviate upwards, in contrast to the very slight flicker of eyelids which may be seen in a typical absence in which the eyes look straight ahead. Brief absences may occur spontaneously and are accompanied by $3 \mathrm{c} / \mathrm{s}$ spike-and-wave discharges. The spike-and-wave discharges seen immediately after eye closure do not occur in the dark. Their presence in a routine EEG is a very reliable warning that abnormality will be evoked by photic stimulation" [1].

JS, also known as eyelid myoclonia with absences (EMA), is a childhood onset epileptic syndrome with manifestations involving a clinical triad of absence seizures with eyelid 
myoclonia (EM), photosensitivity (PS), and seizures or electroencephalogram (EEG) paroxysms induced by eye closure [2].

EMA is considered as a separate entity among genetic generalized epilepsies (GGE) associated with EM and brief absences related to generalized paroxysmal activity on EEG triggered by eye closure or intermittent photic stimulation (IPS) [3,4]. However, epilepsy with eyelid myoclonias has only been recently recognized as a distinct epilepsy syndrome by the International League Against Epilepsy (ILAE) [5].

A family history of seizures or epilepsy is common in those cases (seen in 40-80\%) [4,5]. Additionally, reports of affected identical twins suggest its genetic etiology [4,6-8]. Despite this, there is actually no known gene accepted as pathogenic for this disease [5,9]. Moreover, different case reports have proposed several candidate genes [2,10-13].

EMA onset is typically in childhood, with a peak at 6-8 years. However, the time of seizure onset may be difficult to be exactly established, as eyelid jerks are frequently misinterpreted as tics or mannerisms, and absences may be overlooked [3]. The presence of massive myoclonus, intellectual disability (ID), or slowing of the EEG background are not typical features of the syndrome and may also cause delay in making the correct diagnosis [14]. More frequent in females, some patients show resistance to antiepileptic therapy $[3,4]$.

In clinical practice, however, syndromes may overlap and cases may present with unusual manifestations, posing a diagnostic challenge [14]. The phenotypic and genetic heterogeneity may lead to underestimation of the clinical presentation, making the diagnosis more difficult [15]. In this review, based on different reported cases, we present four candidate genes for EMA and three other genes that might also be related to the disease. Moreover, we discuss their possible relation with the disease in order to improve the knowledge of this syndrome.

\section{Results and Discussion}

\subsection{SYNGAP1}

SYNGAP1 (MIM *603384) is located on 6p21.32 [16]. This gene encodes a brain-specific synaptic Ras GTPase activating protein that is a member of the N-methyl-D-aspartate receptor complex [17]. Primarily expressed in excitatory neurons, it regulates dendritic spines structure, function, and plasticity, with major consequences for neuronal homeostasis and development, crucial for learning and memory [18]. Heterozygous loss of function variants in SYNGAP1 are associated with developmental delay (DD), ID, epilepsy, and autism spectrum disorder (ASD) (MIM \# 612621; ORPHA 544254) [19,20].

In 2011, Klitten et al. described a patient with epilepsy with myoclonic absences and a balanced translocation disrupting SYNGAP1 [12]. This patient presented DD, ID, and ASD, but also eyelid winking and absences associated with eye deviation, being resistant to treatment (Table 1 ).

Mignot et al. (2016) presented a series of 17 unrelated patients with ID and epilepsy, mainly pharmacoresistant ( $>55 \%)$, carrying 13 different loss-of-function SYNGAP1 mutations [21]. Three of them presented EM and suffered from seizures triggered by PS or EEG alteration after eye closure. Even more, one of them carry the missense alteration c.1685C $>\mathrm{T}$ (p.Pro562Leu), which has also been described in another patient diagnosed with EMA with myoclonic-atonic epilepsy (MAE) [22,23] (Table 1). However, this mutation was also recently reported by Lo Barco et al. (2021) in a patient without EM [24]. 
Table 1. Summary of the cases reported with pathogenic (or probably pathogenic) alteration in SYNGAP1 (NM_006772) and an EMA/EMA-like phenotype.

\begin{tabular}{|c|c|c|c|c|c|c|c|c|c|c|}
\hline & & & & & A & & & & & \\
\hline & Reference & Klitten $2011^{1}$ & Mingot $2016^{a}$ & Mingot 2016 & Mingot 2016 & Okazaki $2017^{\text {b }}$ & Vlaskamp $2019^{1}$ & $\begin{array}{l}\text { Vlaskamp } \\
2019^{1} \\
\end{array}$ & $\begin{array}{c}\text { Vlaskamp } \\
2019^{1,2}\end{array}$ & $\underset{1,2}{\operatorname{Vlaskamp}} 2019$ \\
\hline & Patient & & 11 & 12 & 14 & & 1 & 4 & 5 & 7 \\
\hline \multirow{5}{*}{ 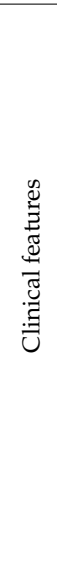 } & gender & Male & Male & Female & Female & Male & Male & Female & Male & Male \\
\hline & Age & $25 \mathrm{yr}$ & $3 \mathrm{yr}$ & $22 \mathrm{yr}$ & $8 \mathrm{yr}$ & $4 \mathrm{yr}$ & 3 yr 10 months & $\begin{array}{l}8 \mathrm{yr} 3 \\
\text { months }\end{array}$ & $\begin{array}{l}11 \mathrm{yr} 2 \\
\text { months }\end{array}$ & 17 \\
\hline & $\mathrm{DD} / \mathrm{ID}$ & + (Severe) & $+($ Severe) & $+($ Severe) & + (Mild) & + & $\begin{array}{l}\text { - (FSIQ: } 80, \text { low } \\
\text { average) }\end{array}$ & + (Mild) & + (Moderate) & $+($ Severe) \\
\hline & $\begin{array}{l}\text { Behavioral } \\
\text { features }\end{array}$ & $\begin{array}{l}\text { ASD traits, anxious } \\
\text { behavior }\end{array}$ & $\begin{array}{l}\text { Repetitive behaviours, } \\
\text { stereotypies }\end{array}$ & Stereotypies & ASD, stereotypies & NR & aveiage) & $\begin{array}{l}\text { ASD traits, } \\
\text { mild } \\
\text { tantrums, } \\
\text { aggression, } \\
\text { high pain } \\
\text { thresholds, } \\
\text { sleeping } \\
\text { problems }\end{array}$ & - & $\begin{array}{l}\text { ASD, regression } \\
\text { severe tantrums, } \\
\text { self-injury, } \\
\text { aggression, high } \\
\text { pain threshold, } \\
\text { sleeping } \\
\text { problems }\end{array}$ \\
\hline & $\begin{array}{c}\text { Other } \\
\text { parametres }\end{array}$ & Absence of language & $\begin{array}{l}\text { Absence of language, truncal } \\
\text { hypotonia, swallowing } \\
\text { difficulties }\end{array}$ & $\begin{array}{l}\text { Absence of language, } \\
\text { mild gait ataxia, } \\
\text { flexion deformity of } \\
\text { left hip, hyperlordotic } \\
\text { lumbar spine, } \\
\text { microcephaly }\end{array}$ & $\begin{array}{l}\text { Motor slowness and } \\
\text { moderate akinesia, } \\
\text { ataxic gait, truncal } \\
\text { hypotonia, dystonic } \\
\text { postures of hands } \\
\text { and feet, plastic } \\
\text { hypertonia }\end{array}$ & $\begin{array}{c}\text { Hypotonia, } \\
\text { hypersalivation }\end{array}$ & - & Hypotonia & - & $\begin{array}{l}\text { Hypotonia, } \\
\text { unsteady gait, } \\
\text { reflux, } \\
\text { obstipation, } \\
\text { eating difficulties, } \\
\text { benign bone } \\
\text { tumor }\end{array}$ \\
\hline \multirow{3}{*}{$\begin{array}{l}\frac{\omega_{2}}{2} \\
\frac{0}{0} \\
\frac{0}{2}\end{array}$} & $\begin{array}{l}\text { Eyelid } \\
\text { myoclonia }\end{array}$ & + (eyelid winking) & + & + & + & NR & + & + & + & + \\
\hline & Photosensitivity & $\mathrm{NR}$ & + & NR & + & + & + & + & + & + \\
\hline & $\begin{array}{l}\text { Other } \\
\text { seizures }\end{array}$ & DA with MJ & FS & FS, MJ & NR & $\begin{array}{l}\text { Upward eye deviation, } \\
\text { motion arrest, loss of } \\
\text { consciousness, and } \\
\text { eyelid twitching. } \\
\text { Triggered by crying and } \\
\text { photosensivility }\end{array}$ & $\begin{array}{l}\text { MS. Triggered by PS, } \\
\text { sounds, sleep } \\
\text { deprivation and } \\
\text { fatigue }\end{array}$ & MS & $\begin{array}{l}\text { FS, MAt, } \\
\text { bilateral TCS. } \\
\text { Triggered by } \\
\text { PS, sleep } \\
\text { deprivation } \\
\text { and fatigue }\end{array}$ & $\begin{array}{l}\text { Bilateral TCS, MS, } \\
\text { FIAS, DA. } \\
\text { Triggered by PS, } \\
\text { eye closure and } \\
\text { eating }\end{array}$ \\
\hline \multirow[t]{2}{*}{ 苮 } & others & $\begin{array}{l}\text { Interictal: generalized } \\
\text { synchronous 3-7 Hz } \\
\text { (P)SW }\end{array}$ & $\begin{array}{c}\text { Abnormal BG, generalized } \\
\text { slowing, EM, and generalized } \\
\text { seizure patterns. Triggered by } \\
\text { photosensivility }\end{array}$ & $\begin{array}{l}\text { Bursts of spikes and } \\
\text { slow waves in the } \\
\text { occipital region after } \\
\text { eye closure. } \\
\text { Triggered by FOS }\end{array}$ & $\begin{array}{c}\text { Ictal: bursts of diffuse } \\
\text { PSW with posterior } \\
\text { predominance after } \\
\text { eyes closer and } \\
\text { photic stimulation. } \\
\text { Triggered by FOS and } \\
\text { PS }\end{array}$ & $\begin{array}{c}\text { Ictal: diffuseslow or SW } \\
\text { activity with occipitalto } \\
\text { central predominance. } \\
\text { Interictal: bilateral } \\
\text { frontal spikes. Sleep: } \\
\text { rhythmic, generalized } \\
\text { 2-3-Hz delta activity, } \\
\text { without visible seizures. } \\
\text { Normal BG }\end{array}$ & $\begin{array}{c}\text { Ictal: GSW } \\
\text { (myoclonic). } \\
\text { Interictal: GSW }\end{array}$ & $\begin{array}{l}\text { BG slow. } \\
\text { Interrictal: } \\
\text { Frequent } \\
2.5-4 \mathrm{~Hz} \\
\text { GSW, after } \\
\text { eye closure } \\
\text { in trains, } \\
\text { MFD }\end{array}$ & $\begin{array}{l}\text { Interictal: } \\
\text { GPW }\end{array}$ & $\begin{array}{l}\text { sleep: frequent } \\
\text { seizures while } \\
\text { falling asleep }\end{array}$ \\
\hline & Cranial MRI & NR & Normal & Normal & Normal & Normal & Normal & Normal & Normal & NR \\
\hline
\end{tabular}


Table 1. Cont.

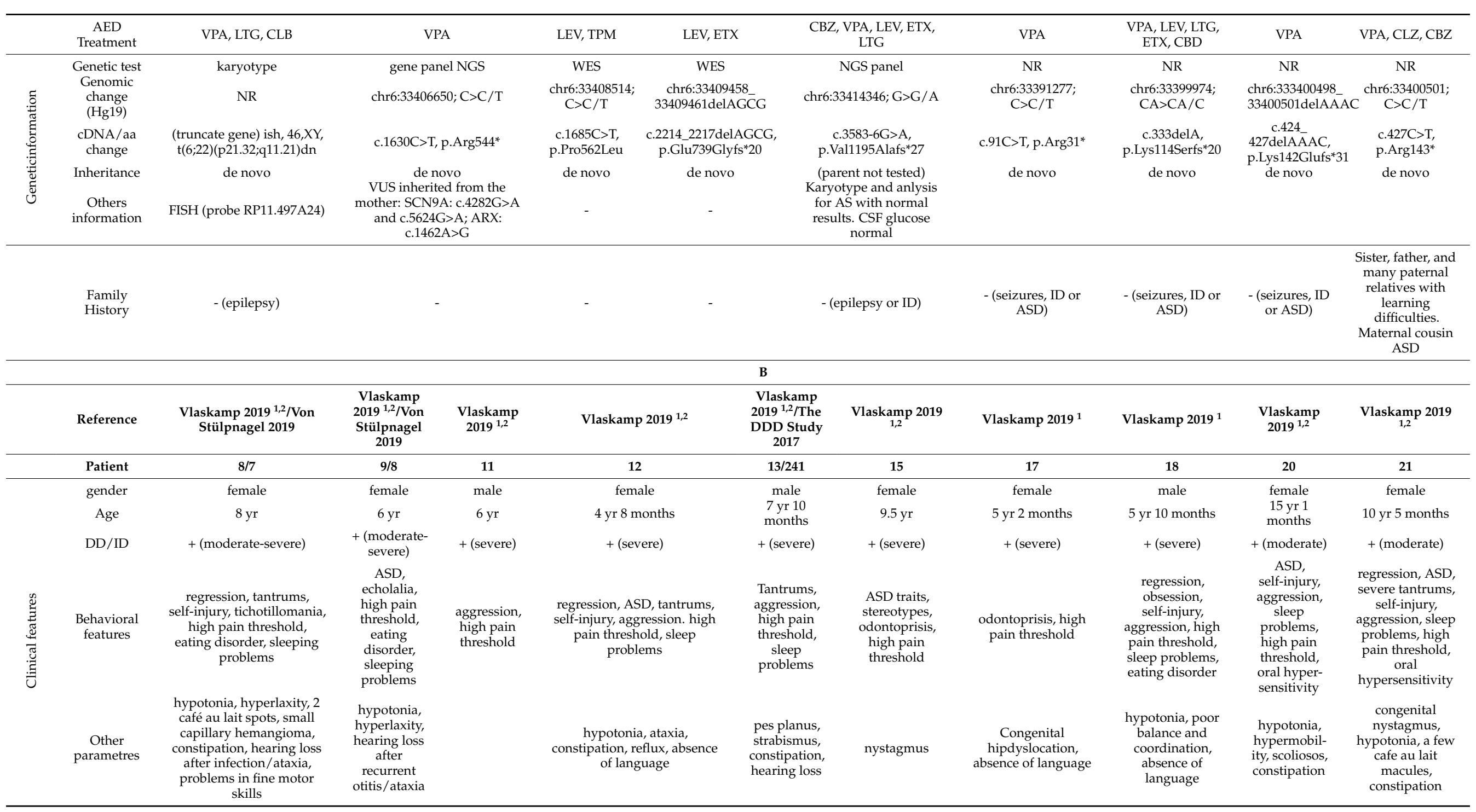


Table 1. Cont.

\begin{tabular}{|c|c|c|c|c|c|c|c|c|c|c|c|}
\hline \multirow{3}{*}{ 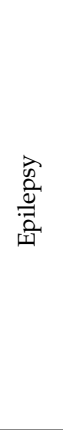 } & \multirow{3}{*}{$\begin{array}{l}\text { Age of onset } \\
\text { Abscence } \\
\text { seizures } \\
\text { Eyelid } \\
\text { myoclonia } \\
\text { Photosensitivity }\end{array}$} & $\begin{array}{c}8 / 16 \text { months } \\
+\end{array}$ & $\begin{array}{c}12-13 \text { months } \\
+\end{array}$ & $\begin{array}{l}4 \mathrm{yr} \\
\mathrm{NR}\end{array}$ & $\begin{array}{l}23 \text { months } \\
+ \text { (AA) }\end{array}$ & $\begin{array}{l}2 \mathrm{yr} \\
\mathrm{NR}\end{array}$ & $\begin{array}{l}2 \mathrm{yr} \\
\mathrm{NR}\end{array}$ & $\begin{array}{c}3.5 \mathrm{yr} \\
\mathrm{NR}\end{array}$ & $\begin{array}{l}3 \mathrm{yr} \\
\mathrm{NR}\end{array}$ & $\begin{array}{l}\text { 12-14 months } \\
+ \text { (MA) }\end{array}$ & \multirow[t]{2}{*}{$2 \mathrm{yrs}$} \\
\hline & & 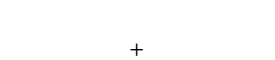 & & & & & 100 & & $10 \mathrm{~N}$ & & \\
\hline & & $\begin{array}{l}+ \\
+\end{array}$ & $\begin{array}{l}+ \\
+\end{array}$ & $\stackrel{+}{N R}$ & $\stackrel{+}{\mathrm{NR}}$ & $\begin{array}{c}+ \\
\mathrm{NR}\end{array}$ & $\begin{array}{c}+ \\
\mathrm{NR}\end{array}$ & $\begin{array}{l}+ \\
+\end{array}$ & $\begin{array}{c}+ \\
\mathrm{NR}\end{array}$ & $\begin{array}{l}+ \\
+\end{array}$ & $\begin{array}{l}+ \\
+\end{array}$ \\
\hline 式 & others & $\begin{array}{l}\text { Intal: } 3 \mathrm{~Hz} \text { GSW } \\
\text { (EM-MAt). } \\
\text { Interictal:G(P)SW }\end{array}$ & $\begin{array}{c}\text { Intal: } 2.5-3.5 \\
\text { Hz GSW } \\
\text { (EM-MAt). } \\
\text { Inerictal: } \\
2.5-3.5 \mathrm{~Hz} \\
\text { GSW }\end{array}$ & $\begin{array}{l}\text { BG poor. } \\
\text { Ictal: } \\
\text { Bilateral } \\
\text { occipital } \\
\text { sharps, } \\
\text { followed by } \\
\text { MFD (EM). } \\
\text { Interictal: } \\
\text { MFD }\end{array}$ & $\begin{array}{l}\text { BG: slow. Ictal: GPSW (MS), } \\
\text { 1.5-2 Hz GSW (AA). Interictal: } \\
\text { GSW facilited by eye closure }\end{array}$ & Interictal: GSW & $\begin{array}{c}\text { BG: slow. Ictal: } \\
\text { FD (unilateral } \\
\text { TCS). Interictal: } \\
\text { 3-4 Hz GSW, } \\
\text { MFD }\end{array}$ & $\begin{array}{l}\text { BG: slow. } \\
\text { Interictal: } 1.5-3 \\
\text { Hz GSW, MFD }\end{array}$ & $\begin{array}{l}\text { Interictal: } 3 \mathrm{~Hz} \\
\text { GSW, bifrotal SW }\end{array}$ & $\begin{array}{l}\text { BG: slow. } \\
\text { Ictal: GSE } \\
\text { (MA). } \\
\text { Inerictal: } \\
\text { MFD }\end{array}$ & $\begin{array}{l}\text { BG: slow. } \\
\text { Interictal: } 3 \mathrm{~Hz} \\
\text { GSW, also } \\
\text { following eye } \\
\text { closure, FD }\end{array}$ \\
\hline$\vec{g}$ & Cranial & Normal & Normal & Normal & Normal & Normal & Normal & Normal & Normal & $\begin{array}{c}\text { Normal } \\
\text { (discrete } \\
\text { hippocampal } \\
\text { tissue loss, } \\
\text { not } \\
\text { progressive } \\
\text { and without } \\
\text { sclerosis) }\end{array}$ & Normal \\
\hline 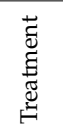 & $\begin{array}{l}\text { AED } \\
\text { Other }\end{array}$ & $\begin{array}{l}\text { VPA, LEV, TPM, CLB, } \\
\text { LTG, ETX, LCM, ZNS, } \\
\text { CLZ, CBD, PHT } \\
\text { KD }\end{array}$ & $\begin{array}{l}\text { CLB, LCM, } \\
\text { ZNS, CLZ, } \\
\text { CBD } \\
\text { KD, mAD }\end{array}$ & $\begin{array}{l}\text { VPA, LEV, } \\
\text { TPM }\end{array}$ & $\begin{array}{c}\text { CLB, TPM, NZP, LTG, VPA, } \\
\text { CLZ }\end{array}$ & VPA, CLB & $\begin{array}{c}\text { VPA, CLZ, LEV, } \\
\text { TPM } \\
\text { Vitamin B6 }\end{array}$ & $\begin{array}{c}\text { VPA, CLZ, LEV, } \\
\text { CLB }\end{array}$ & VPA & $\begin{array}{l}\text { VPA, LEV, } \\
\text { LTG }\end{array}$ & VPA \\
\hline 然 & $\begin{array}{l}\text { Genomic } \\
\text { change } \\
\text { (Hg19) }\end{array}$ & chr6:33400509_334 & 521dup & chr6:33403058delC & elC chr6:33403318dupC & $\begin{array}{c}\text { chr6:33403367; } \\
\quad \text { C }>\text { C / }\end{array}$ & $\begin{array}{l}\text { chr6:33405511_- } \\
\text { 33405512insC }\end{array}$ & $\begin{array}{l}\text { chr6:33406048; } \\
\quad \text { C }>C / T\end{array}$ & chr6:33406202delC & $\begin{array}{l}\operatorname{chr6:33406324;} \\
\quad \mathrm{C}>\mathrm{C} / \mathrm{G}\end{array}$ & $\begin{array}{c}\text { chr6:33408547G } \\
>\text { GGCTGC }\end{array}$ \\
\hline 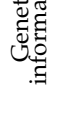 & $\begin{array}{l}\text { cDNA/aa } \\
\text { change } \\
\text { Inheritance }\end{array}$ & $\begin{array}{r}\text { c.435_447dup, p.Le } \\
\text { de novo/mosai }\end{array}$ & $\begin{array}{l}\text { 50Valfs*6 } \\
\text { arent }\end{array}$ & $\begin{array}{l}\text { c.639delC, } \\
\text { p.Ile214Trpfs } * 9 \\
\text { de novo }\end{array}$ & $\begin{array}{l}\text { c.690dupC, } \\
\text { p.Phe231Leufs*14 } \\
\text { de novo }\end{array}$ & $\begin{array}{l}\text { c. } 739 \mathrm{C}>\mathrm{T}, \\
\text { p.Gln} 247^{*} \\
\text { de novo }\end{array}$ & $\begin{array}{c}\text { c.822_823insC, } \\
\text { p.Lys277Glnfs*7 } \\
\text { de novo }\end{array}$ & $\begin{array}{l}\text { c. } 1366 C>T, \\
\text { p.Gln } 456^{*} \\
\text { de novo }\end{array}$ & $\begin{array}{c}\text { c.1393delC, } \\
\text { p.Leu465Phefs*9 } \\
\text { de novo }\end{array}$ & $\begin{array}{c}\text { c. } 1515 \mathrm{C}>\mathrm{G}, \\
\text { p.Tyr505* } \\
\text { de novo }\end{array}$ & $\begin{array}{c}\text { c.1718_ } \\
\text { 1719insGCTGC, } \\
\text { p.Glu578Alafs*74 } \\
\text { de novo }\end{array}$ \\
\hline & $\begin{array}{l}\text { Family } \\
\text { History }\end{array}$ & sisters & & $\begin{array}{l}\text { - (seizures, } \\
\text { ID or ASD) }\end{array}$ & - (seizures, ID or ASD) & $\begin{array}{l}\text { Maternal aunt } \\
\text { and distant } \\
\text { relative epilepsy, } \\
\text { other distant } \\
\text { relatives ASD }\end{array}$ & $\begin{array}{l}\text { - (seizures, ID or } \\
\text { ASD) }\end{array}$ & $\begin{array}{l}\text { - (seizures, ID or } \\
\text { ASD) }\end{array}$ & $\begin{array}{l}\text { Maternal } \\
\text { grandfather } \\
\text { post-stroke } \\
\text { epilepsy }\end{array}$ & $\begin{array}{l}\text { Paternal } \\
\text { uncle } \\
\text { moderate ID }\end{array}$ & $\begin{array}{c}\text { - (seizures, ID or } \\
\text { ASD) }\end{array}$ \\
\hline
\end{tabular}


Table 1. Cont.

\begin{tabular}{|c|c|c|c|c|c|c|c|c|c|c|c|}
\hline & & & & & & C & & & & & \\
\hline & Reference & $\underset{1,2}{\text { Vlaskamp }} 2019$ & Vlaskamp $2019^{1,2}$ & $\begin{array}{l}\text { Vlaskamp } \\
2019^{1}\end{array}$ & $\begin{array}{l}\text { Vlaskamp } 2019 \\
\text { 1/Carvill } 2013 \\
\end{array}$ & $\underset{1}{\text { Vlaskamp } 2019}$ & Vlaskamp $2019^{1}$ & Vlaskamp $2019^{1,2}$ & $\begin{array}{l}\text { Vlaskamp } \\
2019^{1} \\
\end{array}$ & Vlaskamp $2019^{1}$ & Vlaskamp $2019^{1}$ \\
\hline & Patient & 23 & 24 & 25 & $26 / T 2528$ & 27 & 30 & 31 & 32 & 33 & 35 \\
\hline \multirow{5}{*}{ 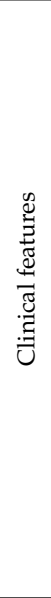 } & gender & female & female & male & male & male & female & male & female & male & male \\
\hline & Age & $11 \mathrm{yr} 11$ months & $7 \mathrm{yr}$ & $\begin{array}{l}11 \text { yr } 7 \\
\text { months }\end{array}$ & $30 / 26 \mathrm{yr}$ & $6 \mathrm{yr}$ & 3 yr 11 months & 11 yr 2 months & $33 \mathrm{yr}$ & 15 yr 3 months & 4 yr 9 months \\
\hline & DD/ID & + (severe) & + (severe) & $\begin{array}{c}+ \\
\text { (moderate) }\end{array}$ & + (moderate) & + (severe) & + (severe) & + (severe) & $\begin{array}{c}+ \text { (moderate- } \\
\text { severe) }\end{array}$ & + (severe) & $\begin{array}{c}+ \text { (moderate- } \\
\text { severe) }\end{array}$ \\
\hline & $\begin{array}{l}\text { Behavioral } \\
\text { features }\end{array}$ & $\begin{array}{l}\text { regression, ASD, } \\
\text { tantrums, } \\
\text { self-injury, } \\
\text { aggression. Sleep } \\
\text { problems, high } \\
\text { paii threshold, } \\
\text { eating } \\
\text { difficulties }\end{array}$ & $\begin{array}{l}\text { regression, ASD, } \\
\text { aggression, sleep } \\
\text { problems, high pain } \\
\text { threshold }\end{array}$ & $\begin{array}{l}\text { ASD, self } \\
\text { injury, } \\
\text { aggression, } \\
\text { sleep } \\
\text { problems, } \\
\text { high pain } \\
\text { threshold }\end{array}$ & $\begin{array}{l}\text { regression, } \mathrm{OCD} \\
\text { symptoms, tantrums, } \\
\text { aggression }\end{array}$ & $\begin{array}{l}\text { regression, ASD, } \\
\text { high pain } \\
\text { threshold }\end{array}$ & $\begin{array}{c}\text { ASD, tantrums, } \\
\text { self-injury, } \\
\text { aggression, sleep } \\
\text { problems, high } \\
\text { pain threshold, } \\
\text { oral } \\
\text { hypersensibility }\end{array}$ & $\begin{array}{c}\text { regression, ASD, } \\
\text { tantrums, aggressive, } \\
\text { sleep problems, high } \\
\text { pain threshold, eating } \\
\text { difficulties }\end{array}$ & $\begin{array}{l}\text { regression, } \\
\text { ASD, } \\
\text { self-injury, } \\
\text { aggression, } \\
\text { poor } \\
\text { concentration, } \\
\text { high pain } \\
\text { threshold }\end{array}$ & $\begin{array}{l}\text { regression, ASD, } \\
\text { aggression, sleep } \\
\text { problems, high pain } \\
\text { thresholds, eating } \\
\text { difficulties }\end{array}$ & $\begin{array}{l}\text { ASD, aggression, } \\
\text { sleep problems, } \\
\text { high pain } \\
\text { threshold }\end{array}$ \\
\hline & $\begin{array}{c}\text { Other } \\
\text { parametres }\end{array}$ & $\begin{array}{l}\text { hypotonia, } \\
\text { constipation }\end{array}$ & $\begin{array}{c}\text { congenital } \\
\text { hisdysplasia, } \\
\text { hypotonia, ataxic gait }\end{array}$ & $\begin{array}{l}\text { pes planus, } \\
\text { hypotonia, } \\
\text { unsteady } \\
\text { gait, } \\
\text { constipation }\end{array}$ & $\begin{array}{l}\text { mild two/three } \\
\text { syndactyly, irregular } \\
\text { tremor upper } \\
\text { extremities, } \\
\text { osteopenia }\end{array}$ & Unsteady gait & $\begin{array}{l}\text { hypotyonia, } \\
\text { unsteady gait, } \\
\text { constipation, } \\
\text { chronic } \\
\text { idiopathic } \\
\text { tromnocytopenic } \\
\text { purpura, absence } \\
\text { of language }\end{array}$ & $\begin{array}{l}\text { microcephaly, short } \\
\text { stature, borderline } \\
\text { hypotonia, ataxia, } \\
\text { Hemangioma nasal } \\
\text { cavity }\end{array}$ & $\begin{array}{c}\text { Hypotonia, } \\
\text { coordination } \\
\quad \text { dis- } \\
\text { oder/ataxia }\end{array}$ & $\begin{array}{l}\text { right pes planus, left } \\
\text { pes caves, hypotonia, } \\
\text { bilateral pyramidal } \\
\text { syndrome, unsteady } \\
\text { gait, orthothics, } \\
\text { hyperflexibility }\end{array}$ & mild hypotonia \\
\hline \multirow{4}{*}{ 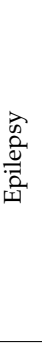 } & $\begin{array}{l}\text { Abscence } \\
\text { seizures }\end{array}$ & NR & NR & NR & + & NR & NR & NR & NR & $\mathrm{NR}$ & NR \\
\hline & $\begin{array}{l}\text { Eyelid } \\
\text { myoclonia }\end{array}$ & + & + & + & + & + & + & + & + & + & + \\
\hline & Photosensitivity & NR & NR & NR & + & NR & NR & NR & + & NR & NR \\
\hline & $\begin{array}{l}\text { Other } \\
\text { seizures }\end{array}$ & $\begin{array}{l}\text { FS, bilateral TCS } \\
\text { (with fiver) }\end{array}$ & $\begin{array}{l}\text { bilateral TCS (with } \\
\text { fiver), atonic DA. } \\
\text { Triggered by fatigue } \\
\text { and illness }\end{array}$ & $\begin{array}{l}\text { Triggered } \\
\text { by eating }\end{array}$ & $\begin{array}{c}\text { FS, aura, FIAS, MJ, } \\
\text { NCSE, bi- and } \\
\text { unilateral TCS, MS. } \\
\text { Triggered by PS }\end{array}$ & $\begin{array}{l}\text { hunger, } \\
\text { self-induced } \\
\text { with hyperventi- } \\
\text { lation, fatigue } \\
\text { and stress }\end{array}$ & TCS (with fiver) & $\begin{array}{l}\text { Atonic DA. Triggered } \\
\text { by sounds, fatigue, } \\
\text { and drop in } \\
\text { emperature }\end{array}$ & $\begin{array}{l}\text { GTCS. } \\
\text { Triggered by } \\
\text { PS }\end{array}$ & - & $\begin{array}{l}\text { Triggered by } \\
\text { eating }\end{array}$ \\
\hline \multirow[t]{2}{*}{ 㦴 } & others & $\begin{array}{l}\text { IBG: Slow. Ictal: } \\
\text { 2-3 Hz GSW } \\
\text { with frontal } \\
\text { maximum, } \\
\text { (EM-AS). } \\
\text { Interictal: MFD }\end{array}$ & Interictal: $2.5 \mathrm{~Hz}$ GSW & NR & $\begin{array}{l}\text { BG: slow. Interictal: } \\
\text { occipital } 2 \mathrm{~Hz} \text { GSW, } \\
\text { occipital } \\
\text { FD/bi-occipital ED, } \\
\text { DS, SSW }\end{array}$ & $\begin{array}{l}\text { BG: iregular. } \\
\text { Ictal: GSW (EM). } \\
\text { Interictal: } 2-3 \\
\text { Hz GSW, } \\
\text { irregular GPSW, } \\
\text { MFD }\end{array}$ & $\begin{array}{l}\text { interictal: } \\
\text { epileptiform } \\
\text { discharge }\end{array}$ & $\begin{array}{l}\text { Ictal: irregular GSW } \\
\text { followed by slower } \\
\text { discharges (EM), } \\
\text { GPWW (EM). } \\
\text { Interictal: G(P)SW, } \\
\text { bifrotal SW, FD }\end{array}$ & NR & $\begin{array}{l}\text { BG: slow Ictal: GSW } \\
\text { (EM). Interictal: } \\
\text { temporo-occipital SW, } \\
10 \% \text { generalized } \\
\text { activity in } 24 \text { hours. }\end{array}$ & $\begin{array}{l}\text { BG: right } \\
\text { occipital slowing. } \\
\text { Ictal: eyeblink } \\
\text { without ictal } \\
\text { correlate. } \\
\text { Interictal: only in } \\
\text { sleep: right } \\
\text { occipital slowing, } \\
\text { focal sharp waves }\end{array}$ \\
\hline & Cranial MRI & Normal & Normal & Normal & Normal & $\begin{array}{l}\text { Patent cavus } \\
\text { vergae }\end{array}$ & $\begin{array}{l}\text { Atypical WM } \\
\text { abnormalities }\end{array}$ & Normal & NR & Enlarged ventricles & Normal \\
\hline
\end{tabular}


Table 1. Cont.

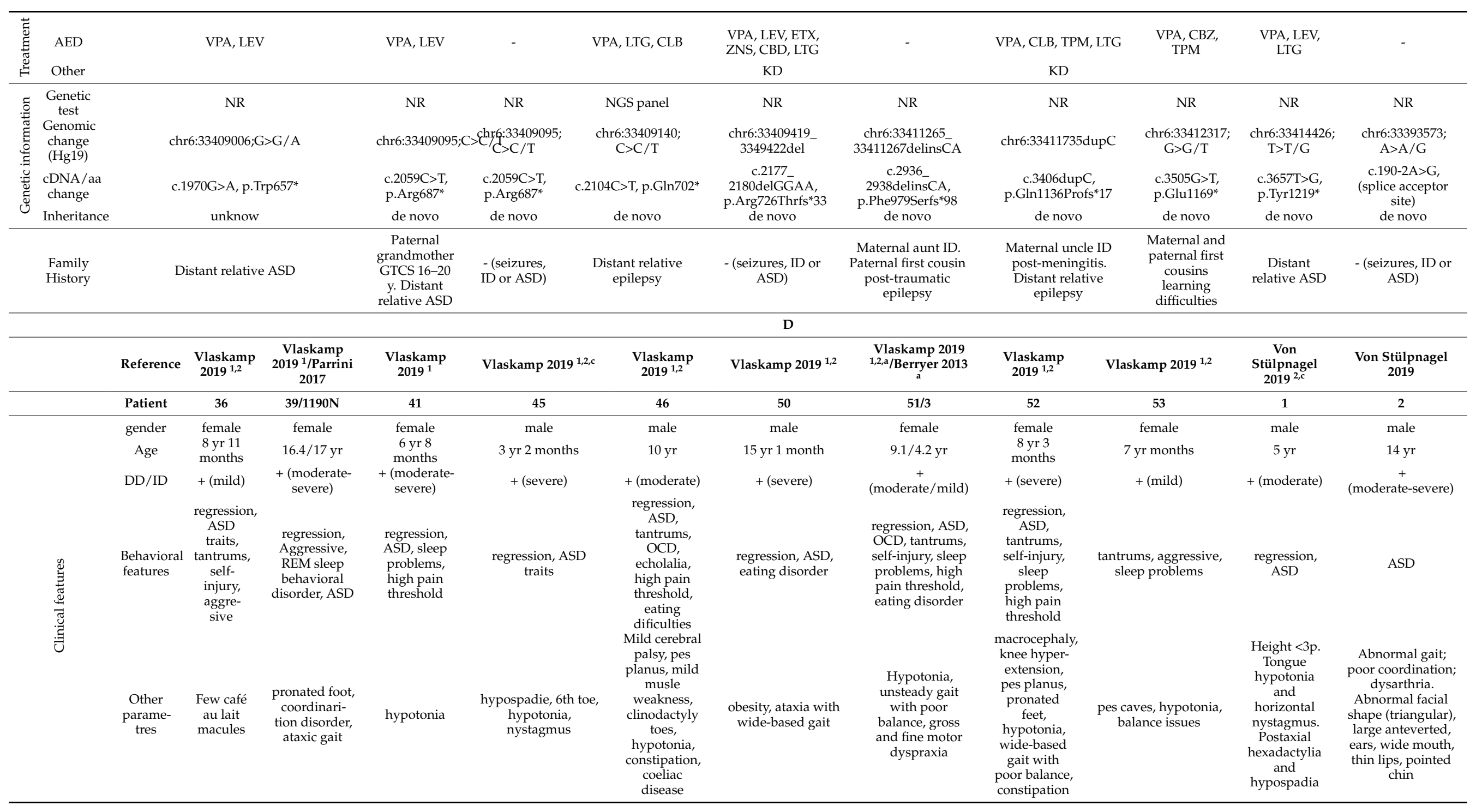


Table 1. Cont.

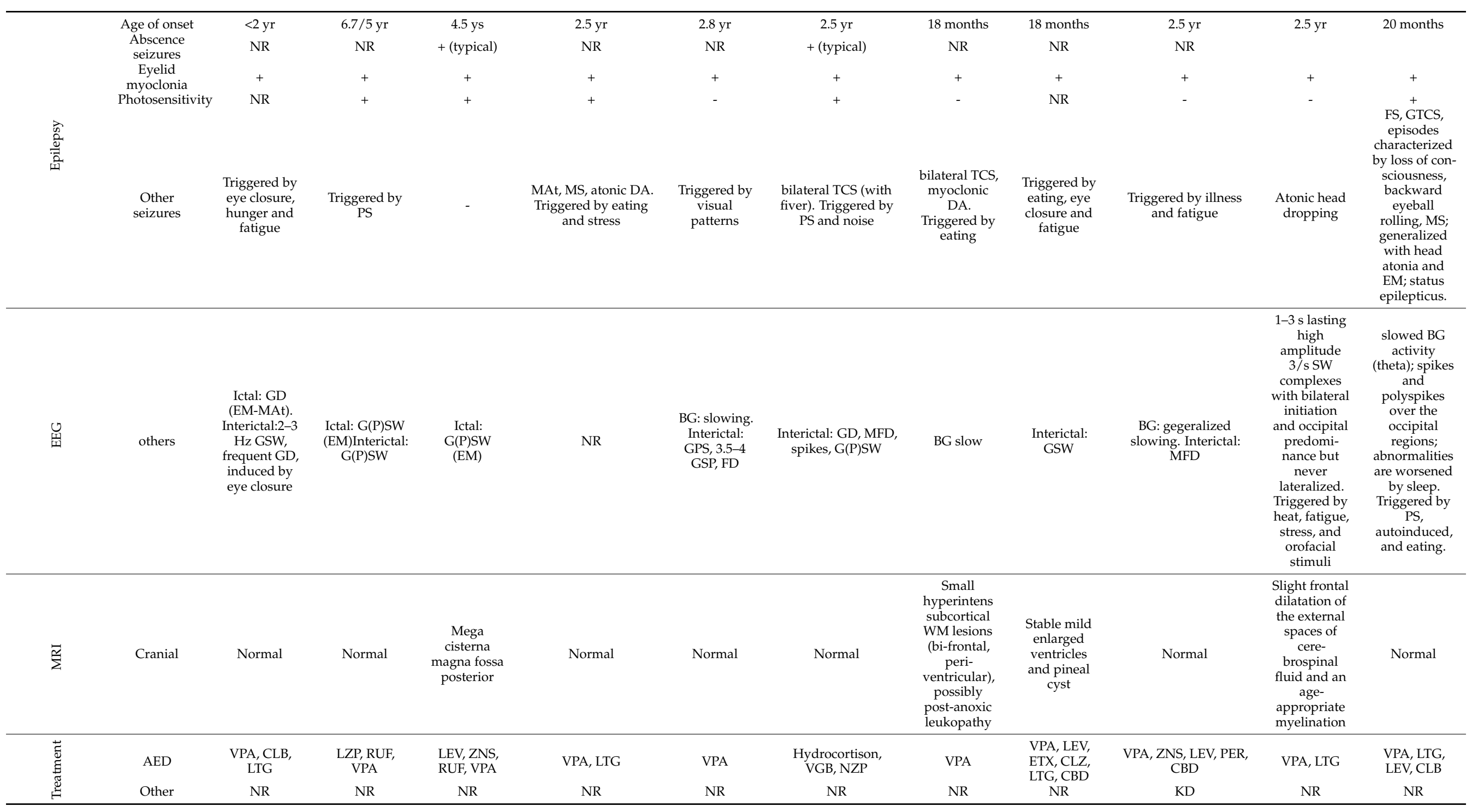


Table 1. Cont.

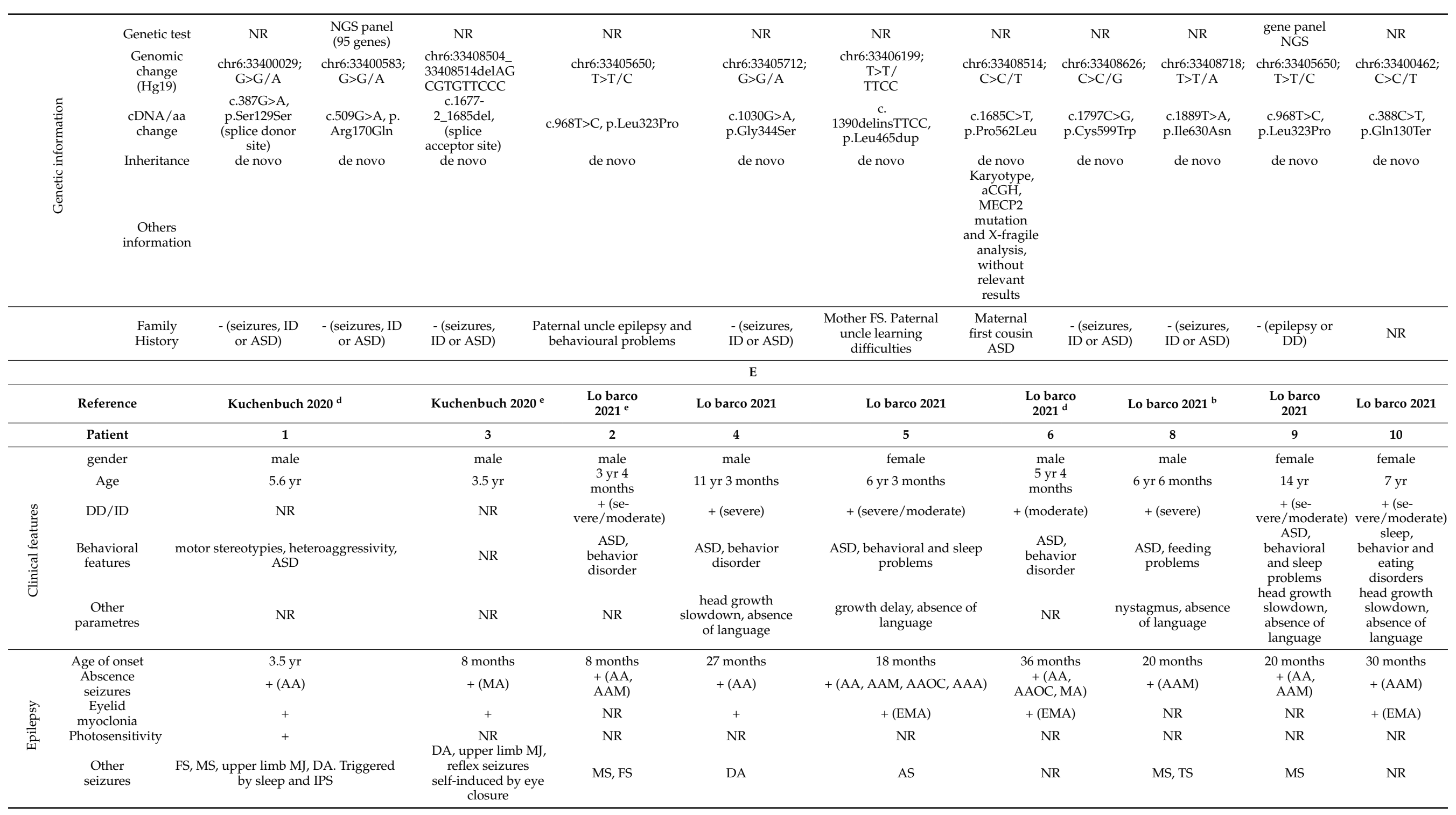


Table 1. Cont.

\begin{tabular}{|c|c|c|c|c|c|c|c|c|c|c|}
\hline 恿 & PPR & NR & 2-HZ GPSW & $\begin{array}{c}+ \\
\text { Sleep: Sporadic } \\
\text { low-voltage multifocal } \\
\text { spikes; sporadic } \\
\text { bursts of generalized } \\
\text { irregular polyspike or } \\
\text { PSW in sleep. EM, } \\
\text { AA, AAM, F. Self } \\
\text { stimulation wirh eyes } \\
\text { closure. }\end{array}$ & $\begin{array}{l}\text { - } \\
\text { Wake: (P)SW on } \\
\text { frontal regions; Sleep: } \\
\text { higher frequency of } \\
\text { generalized } \\
\text { discharges. EM, AA. } \\
\text { Self stimulation wirh } \\
\text { eyes closure. }\end{array}$ & $\begin{array}{c}+ \\
\text { Sleep: Multifocal spikes, } \\
\text { prominent on frontal and } \\
\text { occipital regions; bursts of } \\
\text { generalized irregular } \\
\text { polyspike or PSW. EM, EMA, } \\
\text { AA, AAOC, AS, MS, AAA. } \\
\text { Self stimulation wirh eyes } \\
\text { closure. }\end{array}$ & $\begin{array}{l}+ \\
\text { Sleep: } \\
\text { Low-voltage } \\
\text { centrooccipi- } \\
\text { tal spikes. } \\
\text { AA, AAOC, } \\
\text { MA }\end{array}$ & $\begin{array}{l}\text { Wake: Diffuse GPSW; Sleep: } \\
\text { PSW on frontal regions. EM, } \\
\text { EMA, AA, AAM, MS, AS, } \\
\text { MATS. Self stimulation wirh } \\
\text { eyes closure. }\end{array}$ & $\begin{array}{c}+ \\
\text { Wake: } \\
\text { Diffuse SW, } \\
\text { predominant } \\
\text { on frontal } \\
\text { regions; } \\
\text { Sleep: } \\
\text { Numerous } \\
\text { frontal SW. } \\
\text { EMA, AAM }\end{array}$ & $\begin{array}{l}\text { - } \\
\text { Wake: } \\
\text { Temporo- } \\
\text { parietal SW; } \\
\text { Sleep: PSW } \\
\text { on frontal } \\
\text { regions }\end{array}$ \\
\hline $\overrightarrow{\mathrm{g}}$ & Cranial & Normal & NR & Normal & Normal & $\begin{array}{c}\text { Bilateral hypersignal of WM } \\
(4 \mathrm{yr}) ; \text { cerebellar atrophy (6 } \\
\text { yr) }\end{array}$ & Normal & Aspecific WM hypersignal & NR & $\begin{array}{l}\text { Defect in } \\
\text { frontal lobes } \\
\text { develoment }\end{array}$ \\
\hline \multirow{2}{*}{ 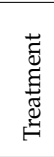 } & AED & $\begin{array}{l}\text { VPA, LEV, ETX, LTG, } \\
\text { CBD }\end{array}$ & $\begin{array}{l}\text { ETX, LEV, LTG, VPA, } \\
\text { CLB, ZNS, PER, CBD }\end{array}$ & VPA, ETX, ZNS, LTG & \multirow[t]{2}{*}{ LEV, VPA } & $\begin{array}{c}\text { VPA, CLB, ETX, LTG, RUF, } \\
\text { ZNS }\end{array}$ & $\begin{array}{l}\text { LEV, VPA, } \\
\text { LTG, ETX }\end{array}$ & $\begin{array}{l}\text { LEV, VPA, TPM, CLB, CLZ, } \\
\text { ZNS, LTG, PER }\end{array}$ & $\begin{array}{l}\text { VPA, LEV, } \\
\text { TPM }\end{array}$ & $\begin{array}{l}\text { LEV, VPA, } \\
\text { LTG, ETX, } \\
\text { CLB, CLZ, } \\
\text { ZNS }\end{array}$ \\
\hline & Other & KD & $\mathrm{KD}$ & KD & & KD, VNS & KD & KD & & \\
\hline \multirow{2}{*}{ 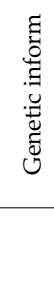 } & $\begin{array}{l}\text { Genomic } \\
\text { change } \\
\text { (Hg19) }\end{array}$ & $\begin{array}{l}\text { chr6:33409002; } \\
\quad \mathrm{G}>\mathrm{G} / \mathrm{T}\end{array}$ & $\begin{array}{l}\text { chr6:33409095; } \\
\quad \text { C }>C / T\end{array}$ & chr6:33409095; C>C/T & chr6:33411544delA & chr6:33405604; T>T/C & $\begin{array}{l}\text { chr6:33409002; } \\
\quad \mathrm{G}>\mathrm{G} / \mathrm{T}\end{array}$ & chr6:33414346; G>G/A & $\begin{array}{l}\text { chr6:33411127; } \\
\quad \mathrm{A}>\mathrm{A} / \mathrm{G}\end{array}$ & $\begin{array}{l}\text { chr6:33400531- } \\
\text { 33400532insG }\end{array}$ \\
\hline & $\begin{array}{l}\text { cDNA/aa } \\
\text { change } \\
\text { Inheritance }\end{array}$ & $\begin{array}{c}\text { c.1966G }>\text { T, p.Glu656* } \\
\text { de novo }\end{array}$ & $\begin{array}{c}\text { c. } 2059 \mathrm{C}>\mathrm{T}, \mathrm{p} . \operatorname{Arg} 687^{*} \\
\text { de novo }\end{array}$ & $\begin{array}{c}\text { c. } 2059 \mathrm{C}>\mathrm{T}, \mathrm{p} . \operatorname{Arg} 687^{*} \\
\text { de novo }\end{array}$ & $\begin{array}{c}\text { c.3215_3224del, } \\
\text { p.Lys1072Serfs*2 } \\
\text { de novo }\end{array}$ & $\begin{array}{c}\text { c. } 922 \mathrm{~T}>\mathrm{C}, \mathrm{p} . \operatorname{Trp} 308 \mathrm{Arg} \\
\text { de novo }\end{array}$ & $\begin{array}{l}\text { c.1966G }>\text { T, } \\
\text { p.Glu656* } \\
\text { de novo }\end{array}$ & $\begin{array}{c}\text { c.3583-6G }>A, \\
\text { p.Val1195Alafs*27 } \\
\text { de novo }\end{array}$ & $\begin{array}{l}\text { c.2798A }>\mathrm{G}, \\
\text { p.His933Arg } \\
\text { de novo }\end{array}$ & $\begin{array}{l}\text { c.456insG, } \\
\text { p.Thr153 } \\
\text { Aspfs*15 } \\
\text { de novo }\end{array}$ \\
\hline
\end{tabular}

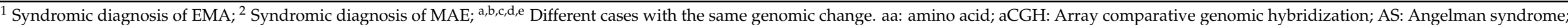

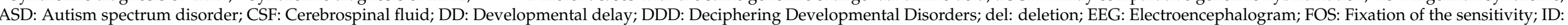

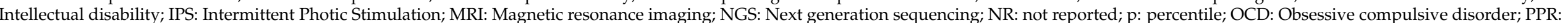

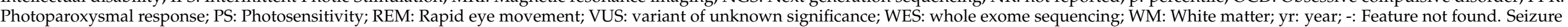

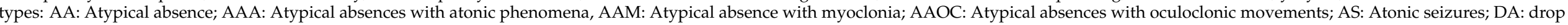

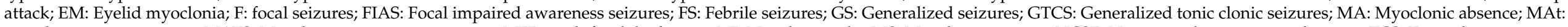

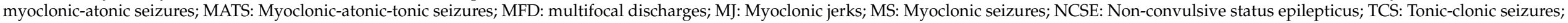

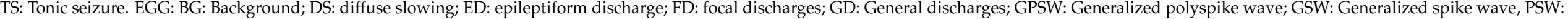

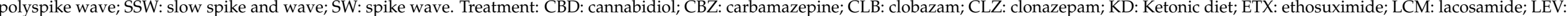

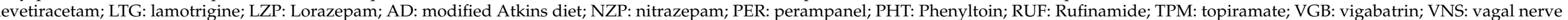
stimulation; VPA: valproate; ZNS: zonisamide. 
Vlaskamp et al. (2019) explored the relationship between EMA and MAE [23]. From a cohort of 57 cases with SYNGAP1 mutations or microdeletions, the most common epilepsy phenotype was an overlapping syndrome combining the features of these two epilepsy syndromes $(20 / 57,35 \%)$, followed by the diagnosis of EMA in 13 patients $(23 \%)$. DD/ID $(32 / 33)$ and ASD (24/33) were also prevalent in those cases (Table 1). According to the results of Vlaskamp et al., absences with EM and PS were found in more than $50 \%$ of the cases with epilepsy and SYNGAP1 alteration. Myoclonic (33\%) and atonic (8\%) seizures were also recurrent in their patients with EM. Moreover, in those cases, EM has an earlier onset and the cognitive outcome is worse than the classic syndrome of EMA. Therefore, they concluded that the more severe cases of EMA might be explained by SYNGAP1 mutations, especially in those individuals with earlier onset of EM or myoclonic or atonic seizures [23].

In this sense, Kuchenbuch et al. (2020) presented three cases with different de novo mutations in SYNGAP1 and epilepsy [25]. Although not all the clinical data are available, two of these cases presented EM and absences induced by PS or eye closure (Table 1). These two cases presented also myoclonic jerks and the EM onset was before 3 years of age (8 months and 2.5 years, respectively) [25]. In addition, the SYNGAP1 variants of these two cases were also reported by Lo Barco et al. (2021) in two other cases with EMA (p.Glu656*) and EM (p.Arg687*) in a cohort of 15 patients with cognitive disability and pathogenic SYNGAP1 variants, of which 14 were epileptic [24]. According to the clinical and EEG data, five of these patients presented EMA, with an onset age of three years or below, presence of myoclonic $(60 \%)$ and atonic $(40 \%)$ seizures in three and two cases respectively, and with uncontrolled seizures despite of the treatment in four cases. Moreover, two more cases of this series also presented EM and absences (Table 1) [24].

Finally, other publications gather more patients with alterations in SYNGAP1 and a phenotype resembling EMA. Okazaki et al. (2017) published a case with a EMA-like phenotype that was carrier of a variant in this gene (p.Val1195Alafs*27) [26]. This alteration was previously identified in a male patient with moderate ID, no speech, psychomotor delay, and behavioral disorders, but without epilepsy [27]. However, this was also later described by Lo Barco et al. in a patient with EMA [24] (Table 1). Von Stülpnagel et al. (2019) published four cases with SYNGAP1 pathogenic variants and EM typically initialed by eye closure [28]. It should be noted that two of them, which were also reported by Vlaskamp et al., were carrier siblings of a variant probably inherited from one of their parents as a result of gonadal mosaicism. Moreover, other variant (p.Leu323Pro) has also been described by Vlaskamp et al. in a patient with a very similar phenotype except for the photosensitivity (Table 1). Furthermore, four more cases of the series from Vlaskamp et al. were previously reported in different publications [22,29-31]. Therefore, a total of 49 patients with a phenotype of EMA or EMA-like, carriers of 44 different pathogenic variants in SYNGAP1, have been reported (Table 1).

\subsection{KIA2022/NEXMIF}

NEXMIF (MIM *300524), also known as KIAA2022, is located on Xq13.3 [32]. NEXMIF encodes for the X-linked Intellectual Disability Protein Related to Neurite Extension (XPN) [33]. Highly expressed in the early brain development, it participates in neurite outgrowth and regulates neuronal migration and cellular adhesion, critical for developing neuronal circuits [33-35]. Loss of function of NEXMIF causes mental retardation X-linked 98 (MRX98; MIM \# 300912) [36]. Like most of X-linked disorders, males tend to be more severely affected than females, whereas carrier females present a wide phenotypic variability and may be unaffected as a result of random X-chromosome inactivation (XCI). MRX98 is a neurodevelopmental disorder characterized in males by delayed motor milestones, lack of language development, moderate to profound ID, behavioral abnormalities such as ASD, hypotonia, postnatal growth restrictions, dysmorphic facial features, and often earlyonset seizures $[36,37]$. Compared with its hemizygous male counterpart, the heterozygous 
female disease has less severe ID, but is more often associated with a severe and intractable myoclonic epilepsy [38,39].

In 2017, Borlot et al. published the case of a women with EMA syndrome carrier of a de novo NEXMIF deletion of $77 \mathrm{~Kb}$, detected by genome-wide oligonucleotide array, within a cohort of 143 adults with unexplained childhood-onset epilepsy and ID [40]. One year later, Myers et al. reported two other sisters diagnosed with MAE with a point mutation at NEXMIF (p.Arg322*) in their search of parental gonadal mosaicism in apparently de novo epileptic encephalopathies [41]. These two cases and their clinical features have recently been reviewed by Stamberger et al. (2021) [42]. Analyzing the phenotype of 87 patients with NEXMIF-related encephalopathy, 10 females were diagnosed with EMA, 2 of them with an earlier onset (one year or younger), and 5 more cases ( 2 males and 3 females) presented a combination of EMA and MAE syndromes, including the case reported by Myers et al. (2018)) (Table 2) [42]. According to Stamberger et al., there was no correlation between phenotype and XCI status in their series, based on 1) the comparison of females with skewed and random XCI and 2) the families with sisters each presenting skewed and random XCI (families F4 and F7). However, it is interesting that in those families, both cases with a skewed XCI were diagnosed with MAE-EMA syndrome without photosensitivity, and their sister with a random inactivation presented a less severe phenotype. Moreover, $\mathrm{XCI}$ testing was performed in blood cells, so that the inactivation rate in neuronal cells is in fact unknown. Additionally, it is remarkable that from the two males, one presented the alteration in a $30 \%$ somatic mosaicism, which may lead to clinical repercussions equivalent to XCI in females (Table 2). On the other hand, the majority of patients with NEXMIFrelated encephalopathy had drug-resistant epilepsy. Although specific information for each patient was not available, only $16 \%$ of the patients from the total cohort were seizure-free. It is outstanding that only $7 \%$ of the females, compared to $47 \%$ of males, were seizure-free $(p=0.001$ Fisher's exact) [42].

Finally, two more female patients with alterations in the NEXMIF gene and a phenotype resembling EMA have been reported. Wu et al. (2020) described a woman with refractory epilepsy and EEG features similar to those described in EMA who was a carrier of a nonsense variant in NEXMIF (p.Leu355*) (Table 2) [43]. Samanta and Willis (2020) identified a frameshift mutation (p.Asp573Serfs*11) in a girl with intractable seizures diagnosed with EMA [2]. She presented a XCI classified as random (ratio 74:26) (Table 2). Based on the results of Viravan et al. (2011) on occipital lobe relation to eye movements in JS, Samanta and Wills proposed that functional brain mosaicism, as a result of random $\mathrm{XCI}$, causes a cellular interference effect responsible for the variable symptoms, with a predominant involvement of a circuit encompassing the occipital cortex and the corti$\mathrm{cal} /$ subcortical systems physiologically involved in the motor control of eye closure and eye movements [2,44].

Summarizing, a total of 15 female patients and 2 males (one of which was a mosaic for the alteration) have been reported with pathogenic variants in NEXMIF and clinical features of EMA (Table 2). 
Table 2. Summary of the cases reported with a pathogenic (or probably pathogenic) alteration in NEXMIF (NM_001008537.3) and an EMA/EMA-like phenotype.

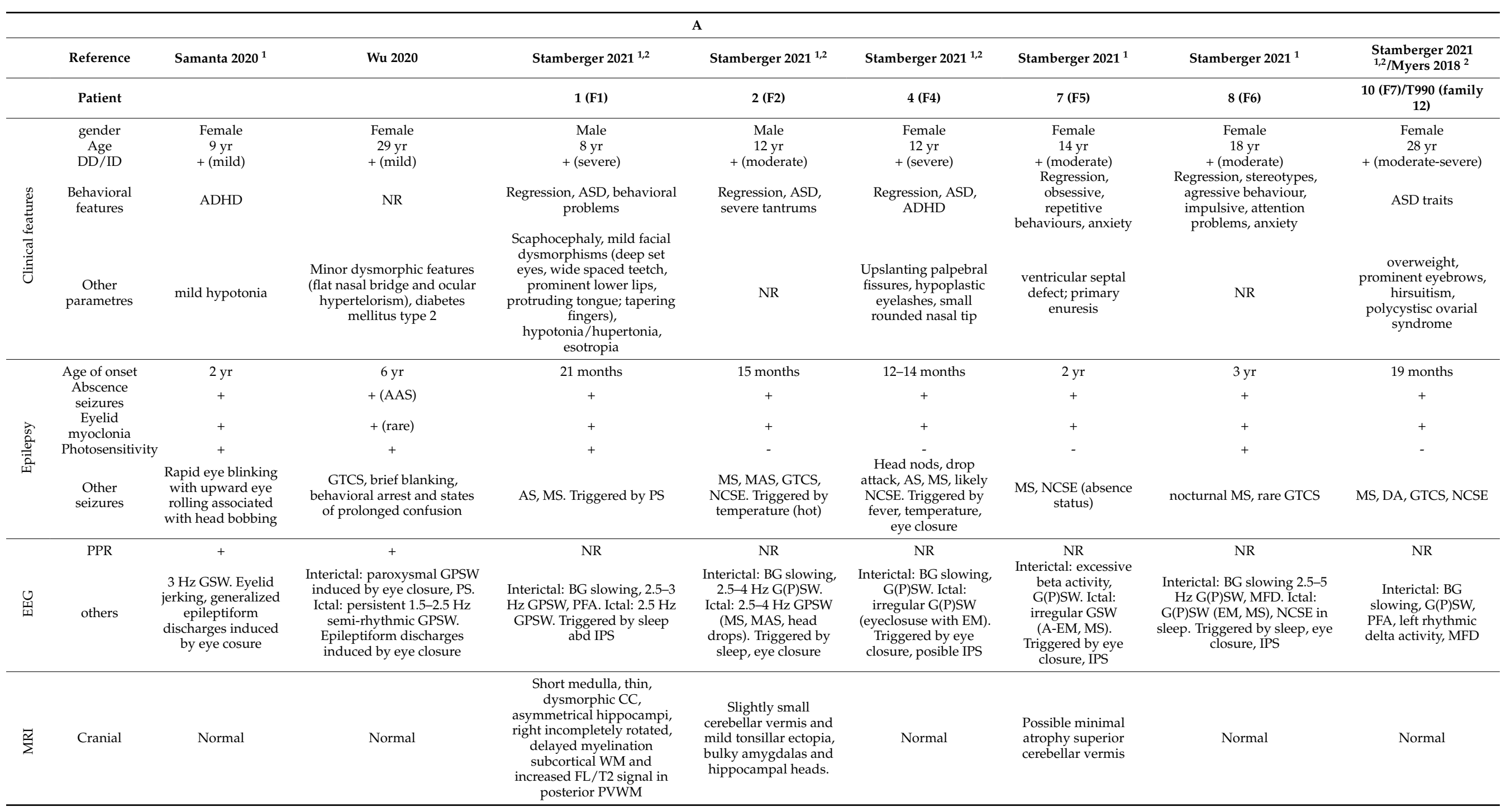


Table 2. Cont.

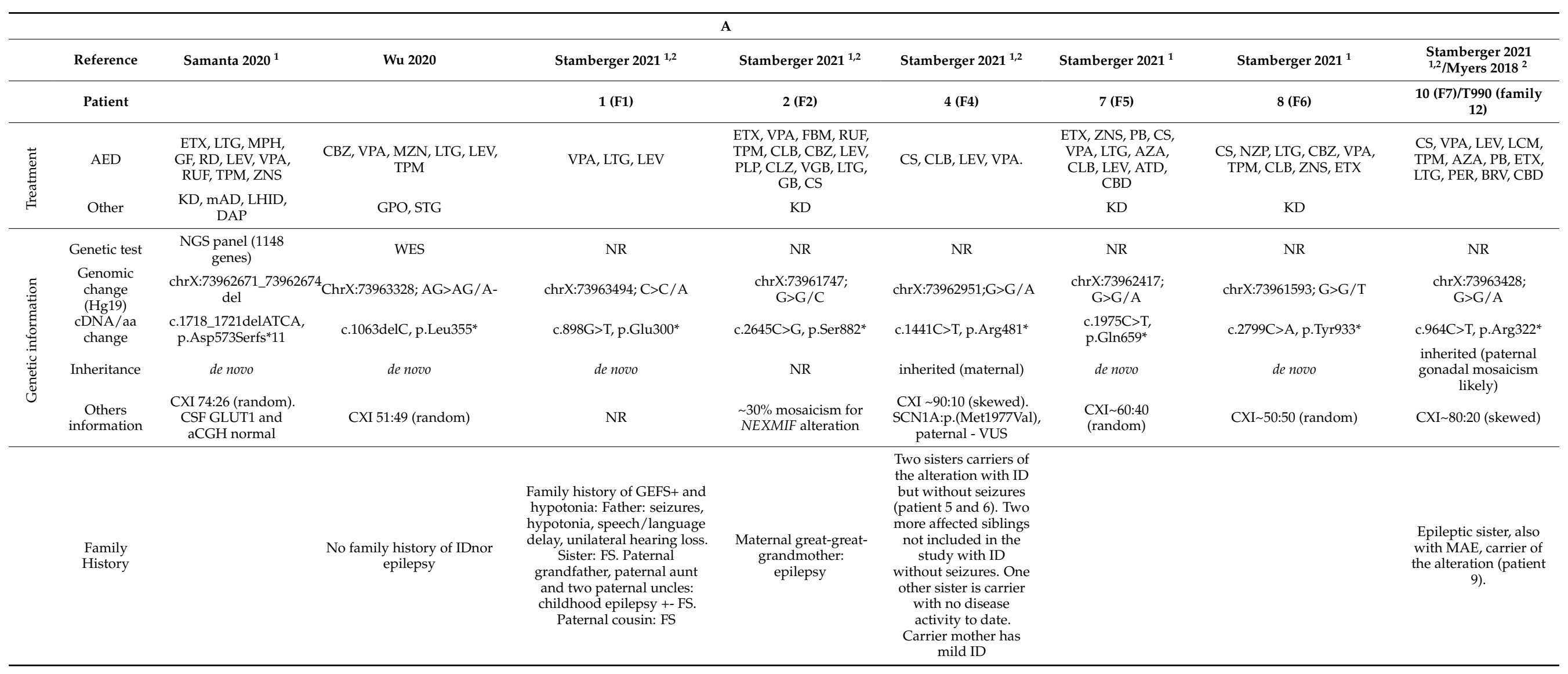


Table 2. Cont.

\begin{tabular}{|c|c|c|c|c|c|c|c|c|c|c|}
\hline & & & & & B & & & & & \\
\hline & Reference & Stamberger 2021 & Stamberger $2021^{1, \#}$ & Stamberger $2021^{1}$ & Stamberger 2021 & Stamberger $2021^{1}$ & Stamberger $2021^{1}$ & $\begin{array}{l}\text { Stamberger } 2021 \\
1 / \text { Borlot } 2017^{1}\end{array}$ & Stamberger 2021 & Stamberger $2021^{1,2,8}$ \\
\hline & Patient & 13 (F10) & 15 (F12) & 16 (F13) & 18 (F15) & 23 (F20) & $33(\mathrm{~F} 30)$ & $34(31) / 27$ & 37 (F34) & 41 (F38 \\
\hline \multirow{3}{*}{ 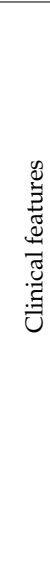 } & $\begin{array}{l}\text { gender } \\
\text { Age } \\
\text { DD/ID }\end{array}$ & $\begin{array}{l}\text { Female } \\
8 \mathrm{yr} \\
+(\mathrm{mild})\end{array}$ & $\begin{array}{c}\text { Female } \\
12 \mathrm{yr} \\
+ \text { (moderate) }\end{array}$ & $\begin{array}{c}\text { Female } \\
10 \mathrm{yr} \\
+(\text { moderate })\end{array}$ & $\begin{array}{l}\text { Female } \\
15 \mathrm{yr} \\
+(\mathrm{mild})\end{array}$ & $\begin{array}{c}\text { Female } \\
16 \text { yr } \\
+ \text { (moderate) }\end{array}$ & $\begin{array}{c}\text { Female } \\
15 \mathrm{yr} \\
+ \text { (moderate) }\end{array}$ & $\begin{array}{l}\text { Female } \\
26 / 23 \mathrm{yr} \\
+ \text { (mild) }\end{array}$ & $\begin{array}{c}\text { Female } \\
10 \mathrm{yr} \\
+(\text { moderate })\end{array}$ & $\begin{array}{l}\text { Female } \\
4 \mathrm{yr} \\
+ \text { (mild) }\end{array}$ \\
\hline & $\begin{array}{l}\text { Behavioral } \\
\text { features }\end{array}$ & $\begin{array}{l}\text { Aggressive } \\
\text { behaviour, } \\
\text { attention } \\
\text { problems }\end{array}$ & ADHD & $\begin{array}{l}\text { ASD, Agressive } \\
\text { behaviour }\end{array}$ & $\begin{array}{l}\text { Self-abasement, } \\
\text { ASD traits (social } \\
\text { difficulties) }\end{array}$ & NR & Easily frustrated & Depression, anxiety & $\begin{array}{c}\text { Attention } \\
\text { deficiency and } \\
\text { problems linked } \\
\text { to } \\
\text { communication } \\
\text { difficulties } \\
\text { during infancy, } \\
\text { decreased satiety, } \\
\text { tics (blinking), } \\
\text { ASD traits. }\end{array}$ & - \\
\hline & $\begin{array}{c}\text { Other } \\
\text { parametres }\end{array}$ & $\begin{array}{l}\text { overweight, } \\
\text { gastro- } \\
\text { oesophageal } \\
\text { reflux disease }\end{array}$ & NR & $\begin{array}{c}\text { Mild facial } \\
\text { dysmorphisms } \\
\text { (short philtrum, } \\
\text { low-set hairline, } \\
\text { mild prognathism } \\
\text { with frontal } \\
\text { bossing) }\end{array}$ & NR & $\begin{array}{c}\text { Hypotonia, } \\
\text { hypermovility }\end{array}$ & NR & $\begin{array}{l}\text { overweight, } \\
\text { gastro-oesophageal } \\
\text { reflux disease as } \\
\text { infant } /-\end{array}$ & $\begin{array}{l}\text { Low set } \\
\text { backward } \\
\text { rotated ears, } \\
\text { protruding } \\
\text { underlip, } \\
\text { hypotonia }\end{array}$ & $\begin{array}{l}\text { Mild hypotonia and } \\
\text { hyperlaxity }\end{array}$ \\
\hline \multirow{3}{*}{ 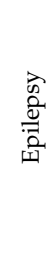 } & $\begin{array}{l}\text { Eyelid } \\
\text { myoclonia }\end{array}$ & + & + & + & + & + & + & + & + & + \\
\hline & Photosensitivity & NR & NR & - & NR & + & - & - & - & + \\
\hline & $\begin{array}{l}\text { Other } \\
\text { seizures }\end{array}$ & $\begin{array}{c}\text { MS, GTCS. } \\
\text { Triggered by } \\
\text { sleep deprivation }\end{array}$ & $\begin{array}{c}\text { Triggered by fever, eye } \\
\text { closure }\end{array}$ & $\begin{array}{l}\text { Triggered bu eye } \\
\text { closure }\end{array}$ & GTCS & $\begin{array}{c}\text { GTCS, NCSE } \\
\text { (absences), Triguered } \\
\text { by PS }\end{array}$ & NR & Single GTCS/BCS & MS & $\begin{array}{c}\text { AS (head drops) MS } \\
\text { (blinking). Triggered } \\
\text { by PS }\end{array}$ \\
\hline \multirow{3}{*}{$\begin{array}{l}\text { y } \\
\text { y } \\
\text { I }\end{array}$} & PPR & NR & NR & NR & NR & NR & NR & NR & NR & NR \\
\hline & others & $\begin{array}{c}\text { Interictal: mild } \\
\text { BG slowing, >3 } \\
\text { Hz G(P)SW, } \\
\text { MFD, GPFA. } \\
\text { Ictal: G(P)SW } \\
\text { (Absences +-EM), } \\
\text { GSW (MS). } \\
\text { Triggered by } \\
\text { sleep, IPS, } \\
\text { hiperventilation }\end{array}$ & $\begin{array}{c}\text { Interictal: normal BG, } \\
\text { G(P)SW in sleep, MFD. } \\
\text { Ictal: GSW (EM), } \\
\text { Triggered by sleep, eye } \\
\text { closure }\end{array}$ & $\begin{array}{l}\text { Interictal: normal } \\
\text { BG, G(P)SW in } \\
\text { sleep, MFD. Ictal: } 3 \\
\text { Hz irregular GPSW } \\
\text { (EM). Triggered by } \\
\text { sleep }\end{array}$ & $\begin{array}{l}\text { Interictal: BG } \\
\text { asimmetry, near } \\
\text { continuous } \\
\text { G(P)SW during } \\
\text { wakefulness. } \\
\text { Ictal: EM with } \\
\text { impaired } \\
\text { awareness }\end{array}$ & $\begin{array}{l}\text { Interictal: Normal BG, } \\
\text { MFD with (P)SW, } \\
\text { multiple spikes. } \\
\text { Triggered by } \\
\text { hyperventilation, IPS, } \\
\text { sleep, eye closure }\end{array}$ & $\begin{array}{c}\text { Interictal: G(P)SW, PFA. } \\
\text { IctalG(P)SW (EM, MS). } \\
\text { Triggered by } \\
\text { hyperventilation, IPS, eye } \\
\text { closure, fixation of sensitivity }\end{array}$ & $\begin{array}{l}\text { Interictal and ictal: } \\
\text { sharply contoured } \\
\text { runs of alpha } \\
\text { activity at } \\
\text { times/polyspike } \\
\text { and generalized } \\
\text { spike waves } \\
\text { induced by eye } \\
\text { closure }\end{array}$ & $\begin{array}{l}\text { Interictal: } \\
\text { multiple spikes } \\
\text { and spike-wave. } \\
\text { Ictal: quick } \\
\text { frontal and } \\
\text { central activity } \\
\text { (MS). Triggered } \\
\text { by eye closure }\end{array}$ & $\begin{array}{l}\text { Interictal: BG } \\
\text { slowing, G(P)SW, } \\
\text { MFD, bifrontal } \\
\text { disrythmic delta } \\
\text { activity during sleep. } \\
\text { Itcal: GPSW (MS). } \\
\text { Triggered by sleep }\end{array}$ \\
\hline & Cranial MRI & Normal & Normal & Normal & Normal & Normal & Normal & Normal & Normal & Normal \\
\hline \multirow{2}{*}{ 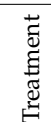 } & AED & ETX, LEV, VPA & $\begin{array}{l}\text { LTG, CLZ, LCM, VPA, } \\
\text { ETX, CLB, LEV }\end{array}$ & ETX, CLZ, VPA & VPA, LTG & $\begin{array}{l}\text { LEV, CLZ, ZNS, VPA, } \\
\text { ETX, OXC, LTG }\end{array}$ & VPA, CLB & TPM, CBZ, VPA & $\begin{array}{l}\text { LEV, LTG, ETX, } \\
\text { VPA }\end{array}$ & CBD, VPA, CLB, LEV \\
\hline & Other & & & & & $\mathrm{KD}, \mathrm{VNS}$ & & vitamin B6 & & \\
\hline
\end{tabular}


Table 2. Cont.

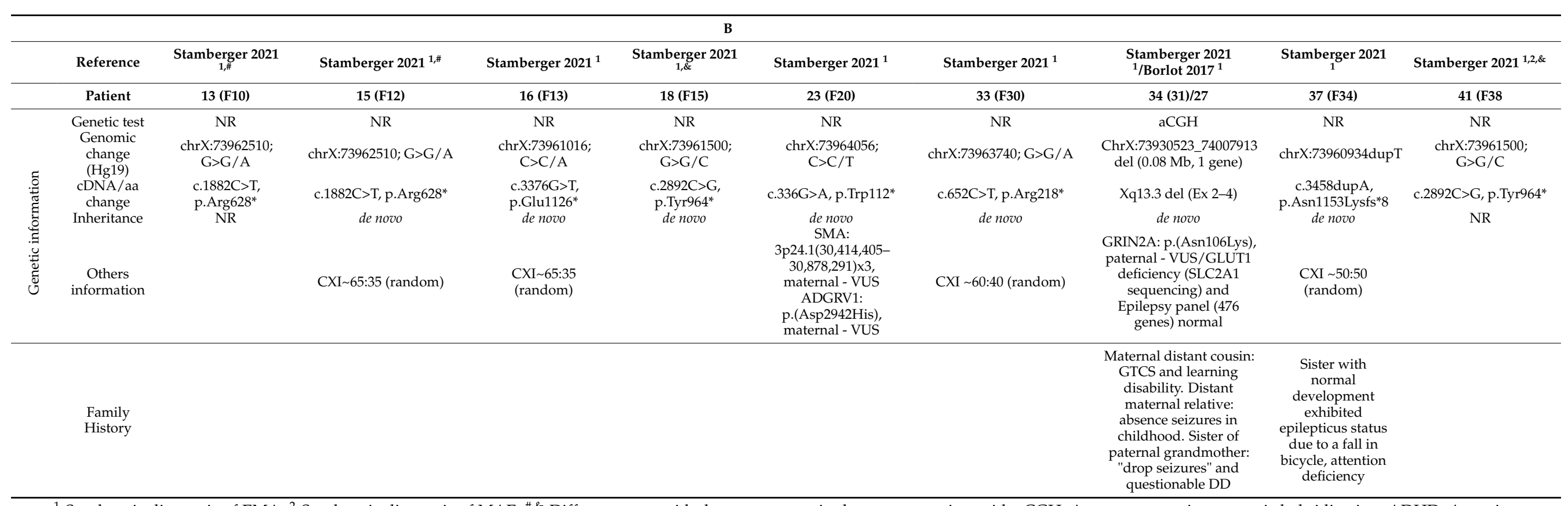

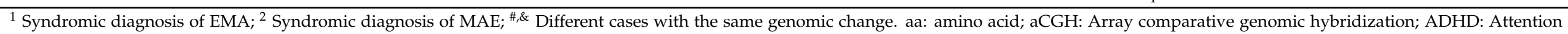

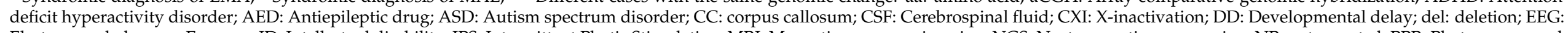

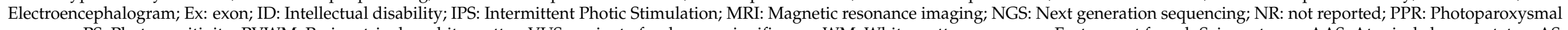

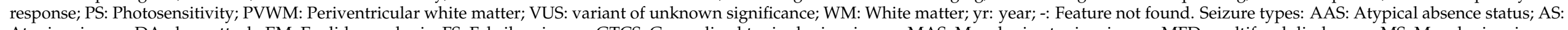

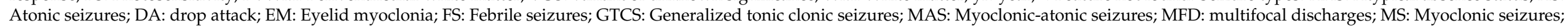

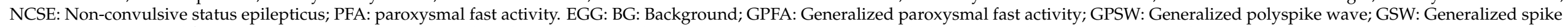

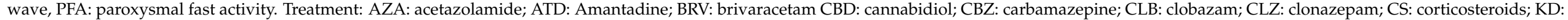

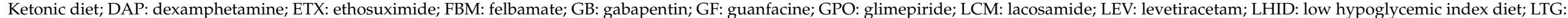

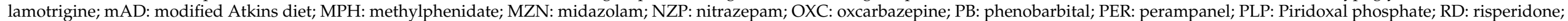
RUF: Rufinamide; STG: sitagliptin; TPM: topiramate; VGB: vigabatrin; VNS: vagal nerve stimulation; VPA: valproate; ZNS: zonisamide. 


\section{3. $R O R B$}

RORB (MIM * 601972) is located on 9p21.13 [45]. This gene encodes for a nuclear receptor, retinoid-related orphan receptor $\beta(\operatorname{ROR} \beta)$, involved in neuronal migration and differentiation [46]. Recent evidences have point out that mutations in this gene may contribute to susceptibility to epilepsy (MIM \# 618357) [47].

In 2012, Bartnik et al., within a cohort of 102 patients, described a case with epilepsy and EM with generalized tonic-clonic seizures (GTCS), carrier of a $2.57 \mathrm{Mb}$ deletion of 6 genes including RORB [48]. A few years later, Rudolf et al. (2016) described a family with four affected family members of EMA with rare GTCS carriers of a nonsense variant in RORB (p.Arg66*) [49]. Other sporadic cases were also reported by these authors with different alteration on $R O R B$, including two more cases with absences, EM and GTCS (Table 3). Sadleir et al. (2020) identified four novel RORB variants in 11 affected patients from four families with different epileptic syndromes [50]. Of this series, one case was diagnosed with EMA and occipital lobe epilepsy, presenting also GTCS. Moreover, another patient from a different family also presented absences with EM and GTCS, but was diagnosed with juvenile absence epilepsy and idiopathic photosensitive occipital lobe epilepsy (Table 3). Although the predominant epileptic phenotype of this cohort was represented by the overlap of photosensitive generalized and occipital epilepsy, the authors underlined the important role of occipital cortex in starting epileptic discharge in idiopathic generalized epilepsies such as EMA [50]. Finally, Morea et al. (2021) described another case with a $R O R B$ variant diagnosed with EMA [11].

Even though only six patients with $R O R B$ alterations, from three different families, have been clearly diagnosed with EMA, interestingly, five of them also presented GTCS. Moreover, four more patients presented EM and absences with GTCS. 
Table 3. Summary of the cases reported with a pathogenic (or probably pathogenic) alteration in RORB (NM_006914) and an EMA/EMA-like phenotype.

\begin{tabular}{|c|c|c|c|c|c|c|c|c|c|c|c|}
\hline & Reference & Bartnik 2012 & Rudolf $2016^{1}$ & Rudolf $2016^{1}$ & Rudolf $2016^{1}$ & Rudolf $2016^{1}$ & Rudolf 2016 & Rudolf 2016 & Sadleir $2020^{1}$ & Sadleir 2020 & Morea $2021^{1}$ \\
\hline & Patient & 12 & 4 & 13 & 14 & 20 & 9A1117 & GE0705 & Familly C II-2 & Family D II-1 & Case report \\
\hline \multirow{5}{*}{ 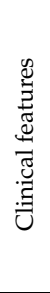 } & gender & Male & Female & Female & Female & Female & Female & Female & Female & Male & Male \\
\hline & Age & NR & NR & NR & NR & NR & $25 \mathrm{yr}$ & $10 \mathrm{yr}$ & $40 \mathrm{yr}$ & $20 \mathrm{yr}$ & $21 \mathrm{yr}$ \\
\hline & $\mathrm{DD} / \mathrm{ID}$ & NR & + (mild) & + (mild) & + (mild) & NR & $+($ mild $)$ & + & $\mathrm{NR}$ & - & + (moderate) \\
\hline & $\begin{array}{l}\text { Behavioral } \\
\text { features }\end{array}$ & ASD & NR & NR & NR & NR & NR & NR & NR & NR & ADHD \\
\hline & $\begin{array}{c}\text { Other } \\
\text { parametres }\end{array}$ & NR & NR & NR & NR & NR & $\begin{array}{l}\text { Macrocephal, overweight, } \\
\text { and learning dificulties }\end{array}$ & $\begin{array}{c}\text { convergent } \\
\text { strabismus, } \\
\text { hypermetropia, } \\
\text { learning } \\
\text { dificulties }\end{array}$ & $\begin{array}{l}\text { Learning } \\
\text { dificulties }\end{array}$ & $\begin{array}{l}\text { Learning } \\
\text { dificulties }\end{array}$ & NR \\
\hline \multirow{5}{*}{$\begin{array}{l}\text { के } \\
\text { 产 } \\
\text { 产 }\end{array}$} & Age of onset & $2 \mathrm{yr}$ & $13 \mathrm{yr}$ & $3 \mathrm{yr}$ & $9 \mathrm{yr}$ & $11 \mathrm{yr}$ & 5 yr 5 months & 4 yr 9 month & $3 \mathrm{yr}$ & $10 \mathrm{yr}$ & $4 \mathrm{yr}$ \\
\hline & $\begin{array}{l}\text { Abscence } \\
\text { seizures }\end{array}$ & $\mathrm{NR}$ & + & + & + & + & + (TA, absence status) & + & + & $\begin{array}{c}+ \text { (absence } \\
\text { status) }\end{array}$ & + \\
\hline & $\begin{array}{c}\text { Eyelid } \\
\text { myoclonia }\end{array}$ & + & + & + & + & + & + & + & + & + & + \\
\hline & Photosensitivity & NR & + & + & + & + & - & + & + & + & $\begin{array}{c}\mathrm{NR} \\
\text { Induced by }\end{array}$ \\
\hline & Other seizures & GTCS & GTCS & GTCS & GTCS & GTCS & GTCS, FS, TC & nocturnal GTCS & $\begin{array}{l}\text { GTCS, occipital } \\
\text { seizures }\end{array}$ & $\begin{array}{l}\text { GTCS, occipital } \\
\text { seizurures, }\end{array}$ & $\begin{array}{l}\text { television and } \\
\text { videogame } \\
\text { exposure }\end{array}$ \\
\hline \multirow{3}{*}{ 㐾 } & PPR & NR & + & + & + & + & NR & NR & + & + & NR \\
\hline & others & CTS & $3 \mathrm{~Hz}$ GSW & $3 \mathrm{~Hz}$ GSW & 3 HZ GSW & $3 \mathrm{~Hz}$ GSW & $\begin{array}{c}\text { Interictal: normal BG } \\
\text { rhythm and bilateral } \\
\text { centrotemporal spikes. } 3 \\
\text { Hz SW absence seizures } \\
\text { activated by } \\
\text { hyperventilation. Ictal } \\
\text { Absence seizures. } \\
\text { Interictal GSW, GPSW. } \\
\text { Focal frontal or temporal } \\
\text { occipital paroxysmal } \\
\text { activity }\end{array}$ & $\begin{array}{c}\text { Absence } \\
\text { seizures } \\
\text { ocassionally } \\
\text { with EM } \\
\text { triggered by IPS. } \\
\text { 3 Hz GSW }\end{array}$ & GSW & GSW & $\begin{array}{l}\text { Ictal: } 3 \text { Hz GSW } \\
\text { Interictal: } \\
\text { asynchronous } \\
\text { spikes on a } \\
\text { physiological } \\
\text { BG rhythm. } \\
\text { Generalized } \\
\text { epileptic } \\
\text { discharges } \\
\text { elicited by eye } \\
\text { closure and } \\
\text { hyperventilation }\end{array}$ \\
\hline & Cranial MRI & NR & NR & NR & NR & NR & Normal & Normal & - & Normal & Normal \\
\hline 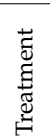 & $\begin{array}{l}\text { AED } \\
\text { Other }\end{array}$ & NR & \multicolumn{4}{|c|}{3 treated with VPA, one with ETX and PB } & $\begin{array}{l}\text { CBZ, VPA, ETX, VGB, } \\
\text { CLB, LTG, TPM, LEV }\end{array}$ & $\begin{array}{l}\text { TEX, VPA, LTG, } \\
\text { LEV } \\
\text { KD }\end{array}$ & LTG, VPA & VPA, LEV, LTG & VPA, ETX, LEV \\
\hline
\end{tabular}


Table 3. Cont

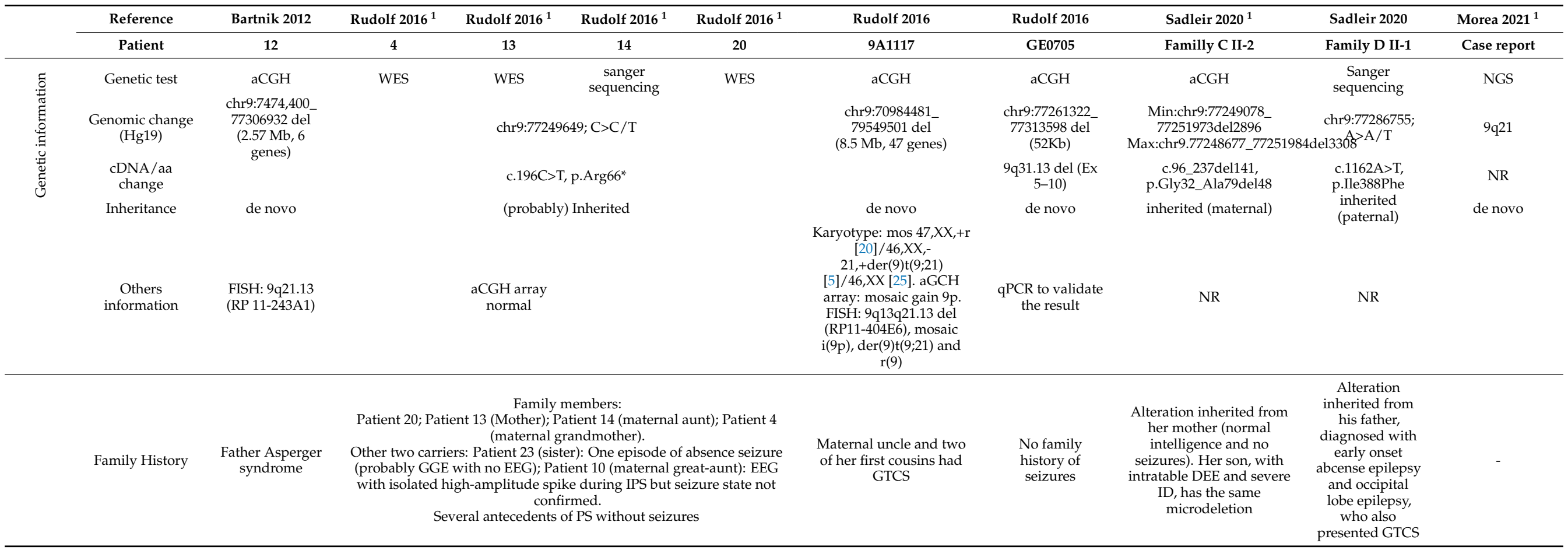

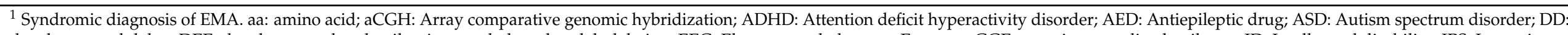

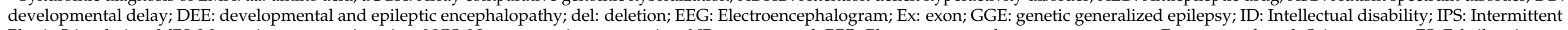

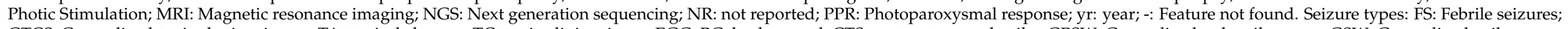

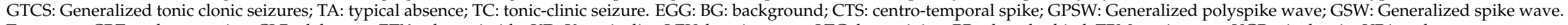
Treatment: CBZ: carbamazepine; CLB: clobazam; ETX: ethosuximide; KD: Ketonic diet; LEV: levetiracetam; LTG: lamotrigine; PB: phenobarbital, TPM: topiramate; VGB: vigabatrin; VPA: valproate. 


\section{4. $\mathrm{CHD} 2$}

CHD2 (MIM *602119) is located on 15q26.1 [51]. It encodes a member of the chromodomain helicase DNA-binding (CHD) family of proteins, of which the canonical function is the gene expression regulation by epigenetic changes in chromatin [52]. Loss of function of CHD2 is identified as a cause of developmental epileptic encephalopathy (DEE) [52], being associated with childhood-onset epileptic encephalopathy (EEOC; MIM \#615369) and MAE (ORPHA 1942) [53,54]. Usually, it is also characterized by cognitive regression, ID, ASD-like phenotype, and resistance to antiepileptic drugs (AED) treatment [52].

Two publications of 2015 underline the association of CHD2 variants with photosensitivity in epilepsy, with seven patients with EMA between both articles $[55,56]$. Thomas et al. presented four cases with EMA, out of 10 patients with de novo CHD2 alterations [56]. The four cases also have GTCS; in addition, other common features associated to CHD2 deficiency were present (ID (4/4), ASD (3/4) and regression (3/4)) (Table 4). On the other hand, Galizia et al. presented the results of a CHD2 screening in a series of more than 500 patients with photosensitive epilepsy [55]. From 36 patients with EMA, all with photoparoxysmal response, three cases presented unique variants in CHD2 (Table 4). Based on the highest frequency of alterations among EMA patients compared to the rest of the series (8/544), the authors considered CHD2 as an important contributor to EMA [55].

Although the number of reported cases with EMA and pathogenic variants in CHD2 is low, it should also be considered in the screening for the genetic causes of this pathology. 
Table 4. Summary of the cases reported with a pathogenic (or probably pathogenic) alteration in CHD2 (NM_001042572) and an EMA/EMA-like phenotype.

\begin{tabular}{|c|c|c|c|c|c|c|c|c|}
\hline & Reference & Galizia $2015^{1}$ & Galizia $2015^{1}$ & Galizia $2015^{1}$ & $\begin{array}{c}\text { Tomas } 2015^{1 / C a r v i l l} \\
2013^{2}\end{array}$ & Tomas $2015^{1}$ & Tomas $2015^{1}$ & $\begin{array}{c}\text { Tomas } 2015^{1 /} \text { Mullen } \\
2013\end{array}$ \\
\hline & Patient & 7 & 8 & 9 & 5/T38 & 6 & 8 & 9/15 [57] \\
\hline \multirow{5}{*}{ 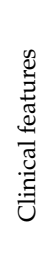 } & gender & NR & NR & NR & Male & Female & Male & Female \\
\hline & Age & NR & NR & NR & $18 / 17 \mathrm{yr}$ & $13 \mathrm{yr}$ & $14 \mathrm{yr}$ & $36 / 26 \mathrm{yr}$ \\
\hline & $\mathrm{DD} / \mathrm{ID}$ & NR & NR & NR & $\begin{array}{c}+ \text { (moderate- } \\
\text { severe/moderate) }\end{array}$ & $+($ moderate-severe $)$ & $+($ mild $)$ & $+($ mild $)$ \\
\hline & Behavioral features & ASD & NR & NR & $\begin{array}{l}\text { ASD, regression, } \\
\text { aggression/ASD, No } \\
\text { regression }\end{array}$ & ASD, ADHD, aggresion & $\mathrm{ADHD}$, regression, agression & $\begin{array}{l}\text { autistic traits, } \\
\text { regression, agression }\end{array}$ \\
\hline & Other parametres & $\begin{array}{l}\text { nephrolithiasis, } \\
\text { migraine, scoliosis }\end{array}$ & NR & NR & $\begin{array}{l}\text { Transient ataxia on } \\
\text { valproate }\end{array}$ & Short stature & Short stature, ataxia & NR \\
\hline \multirow{5}{*}{ 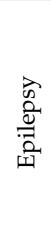 } & Age of onset & NR & NR & NR & 12 months & 30 months & 30 months & 34 months \\
\hline & Abscence seizures & + & + & + & +(AMA, MA; TA $) /+$ & $+(\mathrm{TA})$ & + & \\
\hline & Eyelid myoclonia & + & + & + & & + & + & + \\
\hline & Photosensitivity & + & + & + & $\begin{array}{l}+ \text { (Self induced with } \\
\text { TV) }\end{array}$ & $+($ Self induced with TV) & $\begin{array}{c}\text { +(Self induced with TV; photic } \\
\text { stimulation) }\end{array}$ & $\begin{array}{c}\text { +(Self induced with TV } \\
\text { or light) }\end{array}$ \\
\hline & Other seizures & NR & NR & NR & $\begin{array}{c}\text { MS, FS, GTCS/AS, FS, } \\
\text { MJ, TC }\end{array}$ & $\begin{array}{l}\text { MS (self-induced with TV), TS, } \\
\text { GTCS }\end{array}$ & $\begin{array}{l}\text { AS, GTCS, MS (self-induced with TV), } \\
\text { NCSE, CSE }\end{array}$ & $\begin{array}{c}\text { GTCS, MS } \\
\text { (self-induced with TV } \\
\text { or light), }\end{array}$ \\
\hline \multirow[b]{2}{*}{ 㞻 } & PPR & + & + & + & - (interictal and BG) & - (interictal and BG) & \multirow[b]{2}{*}{$\begin{array}{c}\text { + (grade 4) } \\
32 \text { months: Normal BG, frontal } \\
\text { predominant GSW, GPSW. 5.5 yr: } \\
\text { Normal BG, multifocal GSW. 11 yr: } \\
\text { Diffusely slow BG, } 3 \text { Hz GSW, } \\
\text { bifrontal spikes, activated in sleep, } \\
\text { 4-5 Hz posteriorly dominant GSW on } \\
\text { eye closure. } 12 \text { yr: Continuous } \\
\text { slowing in wake and marked } \\
\text { generalized epileptiform activity in } \\
\text { sleep. . } 44 \text { yr: Diffuse theta slowing, } \\
\text { active interictal GSW GPSW } \\
\text { discharges }>3 \text { Hz increased by } \\
\text { hyperventilation }\end{array}$} & \multirow[b]{2}{*}{$\begin{array}{l}5 \text { yr: Generalized } \\
\text { epileptiform discharge } \\
\text { every } 1-2 \text { minutes }\end{array}$} \\
\hline & others & NR & NR & NR & $\begin{array}{l}\text { 3-4-HZ GPSW during } \\
\text { atonic myoclonic } \\
\text { absence seizures. } 9 \text { yr: } \\
\text { Diffusely slow BG with } \\
\text { symmetrical theta and } \\
3 \mathrm{~Hz} \text { delta. } 14 \text { yr: } \\
\text { Normal BG for brief } \\
\text { bursts of } 3-4 \mathrm{~Hz} \\
\text { regular rhythmic } \\
\text { GSW } 3.8 \mathrm{~Hz} \text { GSW }\end{array}$ & $\begin{array}{l}3 \text { yr: Slow BG for age. Inter-ictal } \\
\text { GSW GPSW, bi frontal slow } \\
\text { spike wave ( } 2 \mathrm{~Hz}) \text {. Eye } \\
\text { flickering-bursts of } 2 \mathrm{~Hz} \\
\text { bifrontal spike and wave. } 4 \text { yr: } \\
\text { EMA, GSW, GPSW. Activated by } \\
\text { eye closure. } 7 \text { yr: Normal BG, } \\
\text { irregular GSW with a frontal } \\
\text { predominance. GSW on eye } \\
\text { closure and during eyelid } \\
\text { myoclonia }\end{array}$ & & \\
\hline$\ddot{\Sigma}$ & Craneal & NR & NR & NR & Normal & $\begin{array}{l}\text { Generalized cerebellar atrophy } \\
\text { with large v4 and prominent } \\
\text { folia. The posterior corpus } \\
\text { callosum is foreshortened and } \\
\text { smaller posteriorly }\end{array}$ & $\begin{array}{l}\text { Atrophy between scans, markedly in } \\
\text { the cerebellum. The corpus callosum } \\
\text { is hypoplastic posteriorly with a } \\
\text { small splenium }\end{array}$ & Normal \\
\hline
\end{tabular}


Table 4. Cont.

\begin{tabular}{|c|c|c|c|c|c|c|c|c|}
\hline & Reference & Galizia $2015^{1}$ & Galizia $2015^{1}$ & Galizia $2015^{1}$ & $\begin{array}{c}\text { Tomas } 2015^{1 / \text { Carvill }} \\
2013^{2}\end{array}$ & Tomas $2015^{1}$ & Tomas $2015^{1}$ & $\begin{array}{c}\text { Tomas } 2015^{1} \text { /Mullen } \\
2013\end{array}$ \\
\hline & Patient & 7 & 8 & 9 & $5 / \mathrm{T} 38$ & 6 & 8 & 9/15 [57] \\
\hline \multirow{4}{*}{ 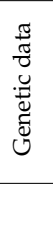 } & Genetic test & NGS & NGS & NGS & target NGS & target NGS & target NGS & $\mathrm{aCGH}$ \\
\hline & $\begin{array}{c}\text { Genomic change } \\
\text { (Hg19) }\end{array}$ & chr15:93540316; A> A/- & $\begin{array}{l}\text { chr15:93545442; } \\
\quad \text {->-/A }\end{array}$ & chr15:93482909; C>C/T & chr15:93545504_93545507del & chr15:93557956delG & $\operatorname{chr15:93521611;C>C/T}$ & $\begin{array}{c}\text { chr15:91027533_93477874 } \\
\text { del }\end{array}$ \\
\hline & $\begin{array}{l}\text { cDNA/aa change } \\
\text { Inheritance }\end{array}$ & $\begin{array}{c}\text { c.3725delA, } \\
\text { p.Lys1245Asnfs*4 } \\
\text { NR }\end{array}$ & $\begin{array}{l}\text { c.4173dupA, } \\
\text { p.Gln1392Thrf*17 } \\
\text { de novo }\end{array}$ & $\begin{array}{l}\text { c.C653T, p.Pro218Leu } \\
\text { inherited }\end{array}$ & $\begin{array}{l}\text { c. } 4235 \text { 4238 delAAGG, } \\
\text { p.Glu1412Glyfs* } 64 \\
\text { de novo }\end{array}$ & $\begin{array}{l}\text { c.4720delG, p.Gly1575Valfs*17 } \\
\text { de novo }\end{array}$ & $\begin{array}{c}\text { c. } 2725 C>\text { T, p.Gln } 909^{*} \\
\text { de novo }\end{array}$ & $\begin{array}{c}15 \mathrm{q} 26 \text { del }(2.4 \mathrm{Mb}) \\
\text { de novo }\end{array}$ \\
\hline & Family History & NR & NR & $\begin{array}{l}\text { Inherited from } \\
\text { unaffected mother }\end{array}$ & NR & NR & NR & NR \\
\hline
\end{tabular}

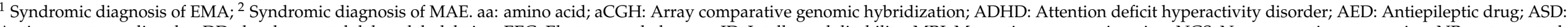

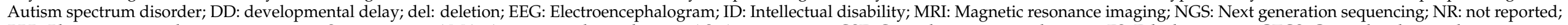

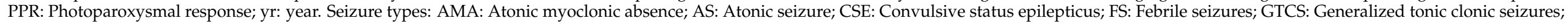

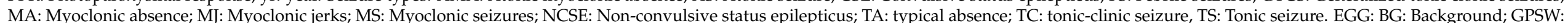
Generalized polyspike wave; GSW: Generalized spike wave. 


\subsection{Other Genes of Interest}

Three publications present different patients with clinical diagnosis of EMA and with a pathogenic variant in three candidate genes for the disease: SLC2A1, KCNB1, and NAA10. The possible implication of these genes in EMA is discussed below.

SLC2A1 (MIM *138140) is located in 1p34.2 and encodes for the major glucose transporter in the brain, GLUT1 [58]. It is responsible for the well-known GLUT1 deficiency syndrome and encephalopathy characterized by a childhood-onset epilepsy refractory to treatment, but with a wide phenotypic variability (MIM \#606777; ORPHA 71277) [59,60]. In this sense, Madann et al. reported a pathogenic variant in SLC2A1 in a family with Glut1-deficiency syndrome and JS [13]. The index case was a 9-year-old boy with intractable seizures since 4 months of age, and frequent absences with EM since 3 years of age. EEG showed eye closure sensitivity (eye closure triggered eyelid myoclonia with absences) and photosensitivity suggestive of EMA. He also presented multifocal seizures and paroxysms of intermittent involuntary gaze; sleep EEG showed multifocal interictal discharges and MRI was normal. Moreover, he had DD, mild ID, gait ataxia, scanning speech, and microcephaly. His father had a history of infantile-onset generalized epilepsy with generalized tonic-clonic seizures and ID, and his paternal uncle also had childhoodonset epilepsy. Metabolic results were suggestive of Glut1-deficiency syndrome; therefore, SLC2A1 was sequenced. A pathogenic variant was detected in both the index case and his father (c.376C > T; p.Arg126Cys), in a hotspot located at a transmembrane domain of the GLUT1, that had been previously reported in other cases with the metabolic syndrome and typical absence seizures or myoclonic absences as the most prevalent seizure type but without EM or EMA features [61,62]. After different unsuccessful treatments with AEDs (valproate, phenobarbital, benzodiazepines, phenytoin, and topiramate), once the molecular diagnosis was known, a ketogenic diet allowed complete seizure remission. However, since it was a targeted study, other genetic causes in the index case could contribute to or be responsible for the EMA phenotype. Furthermore, a screening study of SLC2A1 performed at 25 GGE-EM patients, including 8 cases of EMA, did not identify any variant that could confirm the role of SLC2A1 in EMA or other GEE with EM [63]. Based on these cases, although EMA could be included within the wide phenotypic spectrum for non-classic GLUT1 deficiency syndrome, more evidence is required.

KCNB1 (MIM *600397) is located in 20q13.13 [64]. It encodes for a brain potassium channel (Kv2.1) and its alteration causes a developmental epileptic encephalopathy (DEE26) (MIM \# 616056) [65]. In 2017, from a cohort of six patients with de novo mutations in KCNB1, Marini et al. described two patients with a phenotype resembling EMA. The first case (patient 3) was carrier of a missense variant and was diagnosed with JS [66]. This patient was a 22-year-old female who had had epilepsy since 6 months of age, with bilateral myoclonic jerks. From 7 years of age, she developed absences with EM, frequently on eye closure or autoinduced, with persistent generalized PS. EEG showed generalized spike- and polyspike-wave discharges with a prominent generalized photoparoxysmal response, several episodes of myoclonia and absences with EM were recorded. She also presented myoclonic and tonic-clonic seizures. Trialed with several AEDs (Carbamazepine, valproic acid, levetiracetam, lamotrigine, ethosuximide, clonazepam, and topiramate), she finally became seizure-free with a combination of three of them. She had a delayed early development, evolving into mild cognitive impairment with motor and verbal dyspraxia, poor coordination, and moderate ID [66]. Her KCNB1 variant (c. 916C>T; p.Arg306Cys) was located in the voltage-sensor domain of the protein, which was previously reported in a patient with DD and infantile-onset seizure refractory to therapy but without EMA [67]. A new case with this mutation was also recently reported by Minardi et al. (2020) in a series of 71 patients with DEE [68]. However, few specific clinical data for this case were provided, and EM or EMA-like features were not included among them. On the other hand, the series reported by Marini et al. included a second case with generalized epilepsy with myoclonic seizures and EM with PS; however, unfortunately, this patient was not clearly identified in the article [66]. Therefore, although the data reported by Marini et al. 
were promising, stronger evidence and casuistry are required to consider this gene as a candidate for EMA.

Finally, NAA10 (MIM *300013) is located in Xq28 [69]. It encodes for an N- acetyltransferase and it is responsible for the Ogden syndrome in male carriers, a rare syndrome characterized by postnatal growth failure, developmental delay, hypotonia, and variable dysmorphic features (MIM \# 300855) [70]. Although epilepsy is not associated to this syndrome, Valentine et al. (2018) describe a case with JS and a de novo variant in this gene [10]. The female patient, at the age of 3 years, presented initial seizures described as eye rolling and blank stares without generalized or focal body twitching. At first, she was diagnosed with absence epilepsy. Her seizures were frequently triggered by light stimulation. EEG showed a photoparoxysmal response, characterized by generalized spike-and-slow wave discharges, and numerous eyelid myoclonias with or without absences were recorded. Moreover, her seizures were intractable despite of the AED treatment (clonazepam, levetiracetam, lamotrigine, valproic acid, topiramate, rufinamide, clobazam, intravenous immunoglobulin, modified Atkins diet, and vagal nerve stimulator). Therefore, her epilepsy was consistent with EMA. She also presented DD, normal growth, self-injurious behavior and stereotypies, mild generalized hypotonia, and mild dysmorphisms (clinodactyly, mild ptosis, down slanting palpebral fissures, and tented upper lip) [10]. This patient's NAA10 variant (c.346C>T; p.Arg116Trp) was previously reported in a female patient with random XIC and without known seizure activity, but with other clinical features (normal growth, moderate ID, hypotonia, attention deficit hyperactivity disorder (ADHD), and developmental coordination disorder) [71]. This variant was also reported by Popp et al. (2015) in a male patient with a more severe phenotype (postnatal growth retardation, severe ID, truncal hypotonia and hypertonia of extremities, autistic features, and aggressive behavior) [72]. Moreover, EEG under photic stimulation of this reported male showed generalized epileptic form activity. However, the clinical differences might be due to the inactivation pattern of $X$ chromosome in females, as commented for NEXMIF above.

More cases need to be collected to be able to consider these genes as candidates for EMA. However, in the next-generation-sequencing era, the screening for alteration in those genes in EMA-like patients is manageable and will allow to clarify their promising role in the disease.

\subsection{General Overview of Genetic Interactions}

As mentioned before, the seven genes are expressed in the brain and their function are of great relevance for neuronal development, migration, function, or genetic regulation; however, there is no clear relationship among them. Looking for possible interactions, NEXMIF, highly expressed in fetal and adult brain [73], might be related to $R O R B$, involved in neuronal migration and differentiation [46], and to SLC2A1, essential to provide the requirements of glucose at the brain among other tissues [74] (Figure 1) [75]. However, further studies, including in vitro and animal model assays, would be required to confirm this hypothesis.

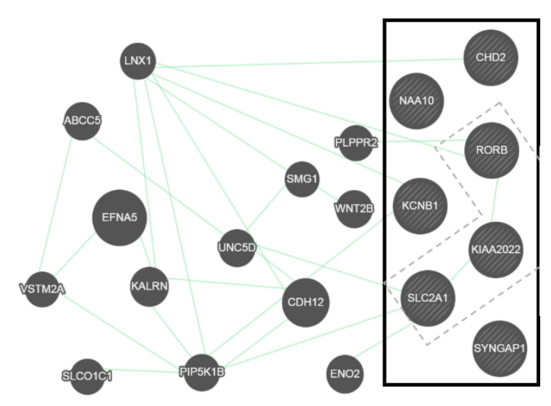

Figure 1. Prediction of the genetic interactions performed by Genemania (http:/ / genemania.org/ (accessed on 15 April 2021) [75]. 


\subsection{Animal Models}

Gene editing techniques have facilitated the generation of mouse models of human diseases; however, very little is known specifically about EMA. SYNGAP1 haploinsufficient young mice showed a reduced fluorothyl-induced seizure threshold and were prone to audiogenic seizures [76]. Furthermore, it is worth noting that in the former study, photostimulation evoked signals originating in the dentate gyrus were dramatically amplified as they spread through the hippocampus, instead of attenuated as it occurs in wild type animals. In addition, germline Syngap1 mutations in mice induced a persistent form of stabilized cortical hyperexcitability that lasted into adulthood, with the seizure threshold remaining reduced [77]. Interestingly, restoration of the gene in adult mice was able to improve behavioral and electrophysiological measures of memory and seizures [78]. Finally, the phenotype of the epileptogenesis in a Syngap1 $1^{+/}$mouse model have been recently described [79]. On the other hand, loss of NEXMIF gene expression in neurons of Knock-out (KO) mice results in a significant decrease in synapse density and synaptic protein expression [80]. These animals presented severe seizures, although further studies are required to characterize the epileptic phenotype in Nexmif $\mathrm{KO}$ mouse models.

\section{Methods}

Systematic literature research of PubMed was performed to identify eligible articles until 31 March 2021 (see Appendix A for complete search terms). The search identified 66 potential articles.

Reviews, clinical trials, and articles in a different language than English were excluded. We screened the titles and abstracts to check if they were within the scope of this review. In some cases, when abstracts were not available or more information was required to decide, a quick review of the whole article was carried out. At this stage, a total of 21 original articles, mainly case reports, containing data dealing with candidate genes for EMA, were obtained (Figure 2). For each of the seven selected genes, a literature research was also performed to look for more cases with an EMA-like phenotype. This selection was based on different number of cases for each gene: 49 for SYNGAP1 (Table 1); 17 for NEXMIF (Table 2); 10 for RORB (Table 3); 7 for CHD2 (Table 4); 2 cases for KCNB1; and 1 case each for SLC2A1 and NAA10. It is also remarkable that some of these cases were reported in different publications (Tables 1, 2 and 4).

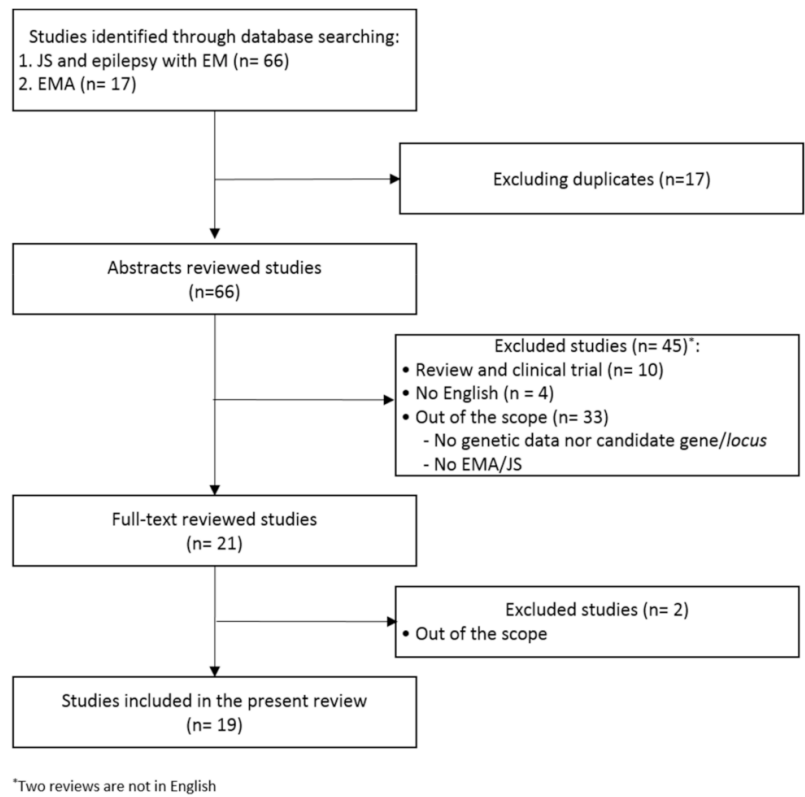

Figure 2. Flow diagram summarizing the systematic search, screening, and studies selection for this review. 


\section{Conclusions}

Loss of function of SYNGAP1, in addition to its association with DD, ID, and ASD, might be considered in epileptic patients with EMA, especially in those cases with earlier onset of EM, pharmacoresistance, or myoclonic or atonic seizures.

The phenotype spectrum of NEXMIF in females (or mosaic males) may also include EMA-like, probably associated with pharmacoresistance. Since this gene is located in the $\mathrm{X}$ chromosome, $\mathrm{XCI}$ in the brain can causes specific cellular mosaicism that might be responsible for the EMA phenotype in those cases.

In patients with alterations in SYNGAP1 or NEXMIF, clinical features of EMA may overlap with MAE syndrome, presenting manifestations of both pathologies. It is also remarkable that despite the relative low number of cases with pathogenic alteration in those genes, two families presented a probably gonadal mosaicism: one family presented with a frame shift mutation in SYNGAP1 (p.Leu150Valfs*6) and the other with a nonsense variant in NEXMIF (p.Arg322*) (Tables 1 and 2). The recurrence of gonadal mosaicism is very variable depending on the disease but has to be taken into account for correct genetic counseling [81].

Regarding $R O R B$ and $C H D 2$, although the number of cases with EMA is significantly lower, they should be taken into account, especially in those cases with GTCS.

In relation to other genes, a few cases of EMA have been reported with variants in SLC2A1, KCNB1, or NAA10. There is not enough information to establish a clear relationship, but as more and more exome and genome studies in EMA patients are performed, it is expected that their role in the molecular diagnosis of this pathology will be clarified.

It is remarkable that two of the seven genes are located in the $\mathrm{X}$ chromosome, NEXMIF and NAA10. Although males show an apparently more severe phenotype, females more often present severe and intractable epilepsy. As mentioned before, random XCI in the brain might lead to cellular interference responsible for the epilepsy and could also explain the higher prevalence of EMA in females.

Finally, an animal model is a great tool to study the pathobiology of complex human disease that affect organs such as the brain. Although mouse models have shown some results regarding SYNGAP1 and NEXMIF haploinsufficiency, no specific data have been collected for EMA. Therefore, to establish the possible interaction between these seven genes, or their direct implication into the pathology, further functional studies are required.

Author Contributions: Conceptualization, S.M. and J.B.-L.; methodology, S.M., I.G.-M., and F.J.F.-M.; resources, S.M. and I.G.-M.; data curation, S.M., A.C., and F.M.; writing-original draft preparation, S.M.; writing, review and editing, F.M. and A.C.; visualization, S.M. and J.B.-L.; supervision, J.B.-L. All authors have read and agreed to the published version of the manuscript.

Funding: This research was funded by the Mutua Madrileña Foundation (FMM), grant number 2019/0144. S.M. was funded by a postdoctoral "Sara Borell” grant CP20/00154 from the Health Institute Carlos III (Spanish Ministry of Science and Innovation).

Conflicts of Interest: The authors declare no conflict of interest.

\section{Appendix A}

PubMed search terms:

1. ((Jeavons Syndrome) OR (epilepsy with eyelid myoclonias)) AND (genetic OR gene OR genes)

2. ("Eyelid myoclonia with absences") AND (genetic OR gene OR genes) 


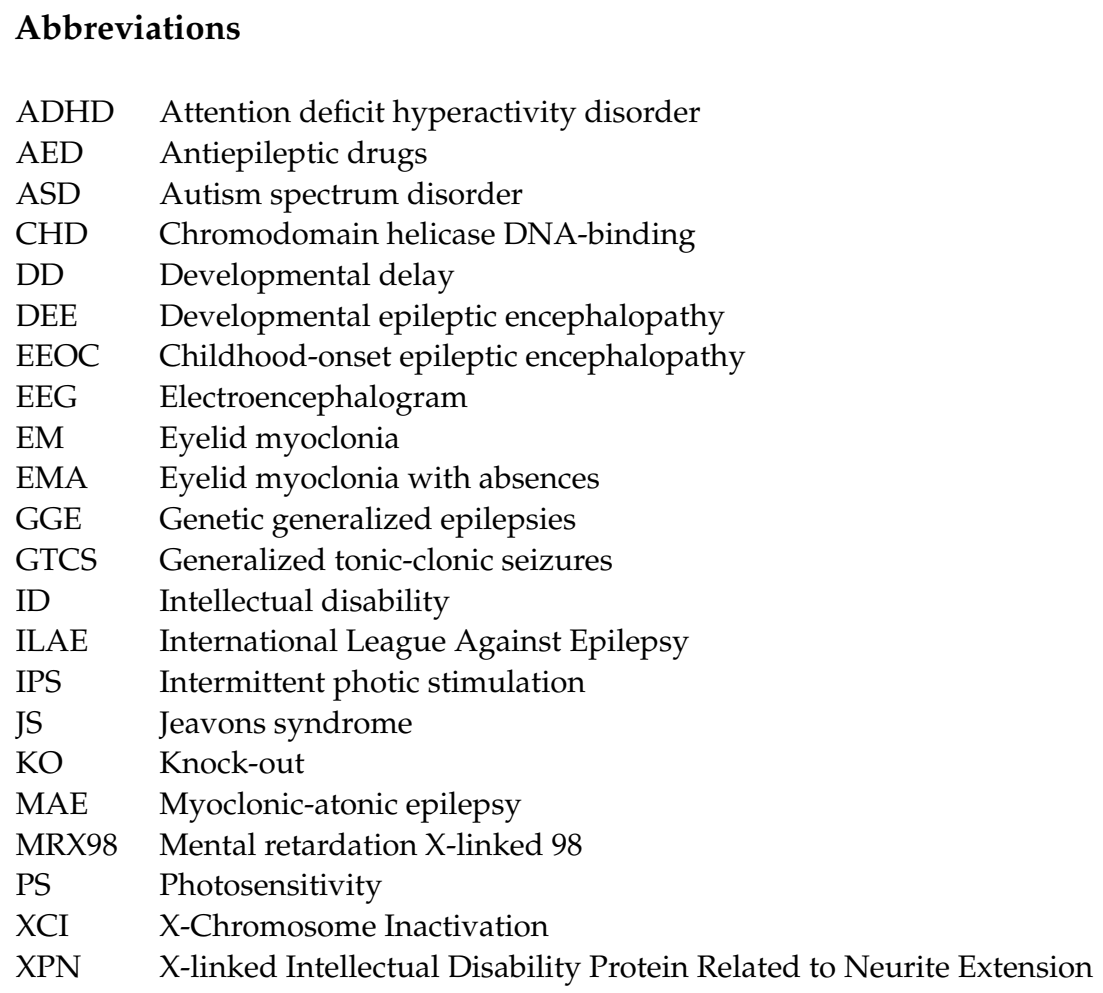

\section{References}

1. Jeavons, P.M. Nosological Problems of Myoclonic Epilepsies in Childhood and Adolescence. Dev. Med. Child Neurol. 1977, 19, 3-8. [CrossRef]

2. Samanta, D.; Willis, E. KIAA2022-related disorders can cause Jeavons (eyelid myoclonia with absence) syndrome. Acta Neurol. Belg. 2020, 120, 205-207. [CrossRef] [PubMed]

3. Striano, S.; Capovilla, G.; Sofia, V.; Romeo, A.; Rubboli, G.; Striano, P.; Trenité, D.K.N. Eyelid myoclonia with absences (Jeavons syndrome): A well-defined idiopathic generalized epilepsy syndrome or a spectrum of photosensitive conditions? Epilepsia 2009, 50, 15-19. [CrossRef]

4. Striano, S. Eyelid myoclonia with absences: An overlooked epileptic syndrome?Les myoclonies des paupières avec absences: Un syndrome épileptique sous-estimé ? Neurophysiol. Clin. Neurophysiol. 2002, 32, 287-296. [CrossRef]

5. International League against Epilepsy. Epilepsy with Eyelid Myoclonias. Available online: https://www.epilepsydiagnosis.org/ syndrome/emwa-overview.html (accessed on 1 April 2021).

6. Parker, A.; Gardiner, R.; Panayiotopoulos, C.P.; Agathonikou, A.; Ferrie, C.D. Observations on families with eyelid myoclonia with absences. In Eyelid Myoclonia with Absences; Duncan, J.S., Panayiotopoulos, C.P., Eds.; John Libbey Ltd.: London, UK, 1996; pp. 107-115.

7. Demarco, P. Eyelid Myoclonia with Absences (EMA) in Two Monovular Twins. Clin. EEG Neurosci. 1989, 20, 193-195. [CrossRef] [PubMed]

8. Adachi, M.; Inoue, T.; Tsuneishi, S.; Takada, S.; Nakamura, H. Eyelid myoclonia with absences in monozygotic twins. Pediatr. Int. 2005, 47, 343-347. [CrossRef] [PubMed]

9. Striano, P. Orphanet Encyclopedia Jeavons Syndrome. Available online: https://www.orpha.net/consor/cgi-bin/OC_Exp.php? lng=EN\&Expert=139431\#: \{\}:text=Disease (accessed on 1 April 2021).

10. Valentine, V.; Sogawa, Y.; Rajan, D.; Ortiz, D. A case of de novo NAA10 mutation presenting with eyelid myoclonias (AKA Jeavons syndrome). Seizure 2018, 60, 120-122. [CrossRef] [PubMed]

11. Morea, A.; Boero, G.; Demaio, V.; Francavilla, T.; La Neve, A. Eyelid myoclonia with absences, intellectual disability and attention deficit hyperactivity disorder: A clinical phenotype of the RORB gene mutation. Neurol. Sci. 2021, 42, 2059-2062. [CrossRef] [PubMed]

12. Klitten, L.L.; Møller, R.S.; Nikanorova, M.; Silahtaroglu, A.; Hjalgrim, H.; Tommerup, N. A balanced translocation disrupts SYNGAP1 in a patient with intellectual disability, speech impairment, and epilepsy with myoclonic absences (EMA). Epilepsia 2011, 52, 190-193. [CrossRef]

13. Madaan, P.; Jauhari, P.; Chakrabarty, B.; Gulati, S. Jeavons syndrome in a family with GLUT1-deficiency syndrome. Seizure 2019, 71, 158-160. [CrossRef] [PubMed]

14. Dragoumi, P.; Emery, J.; Chivers, F.; Brady, M.; Desurkar, A.; Cross, J.H.; Das, K.B. Crossing the lines between epilepsy syndromes: A myoclonic epilepsy variant with prominent eyelid myoclonia and atonic components. Epileptic Disord. 2018, $20,35-41$. [CrossRef] [PubMed] 
15. Reyhani, A.; Özkara, Ç. Pitfalls in the diagnosis of Jeavons syndrome: A study of 32 cases and review of the literature. Epileptic Disord. 2020, 22, 281-290. [CrossRef] [PubMed]

16. Online Mendelian Inheritance in Man, OMIM®. Johns Hopkins University, Baltimore, M.D. SYNAPTIC RAS-GTPaseACTIVATING PROTEIN 1; SYNGAP1. Number: * 603384. Available online: https:/ / www.omim.org/entry/603384 (accessed on 1 April 2021).

17. Gene [Internet]. Bethesda (MD): National Library of Medicine (US) National Center for Biotechnology Information. SYNGAP1 Synaptic Ras GTPase Activating Protein 1 [Homo Sapiens (Human)] Gene ID: 8831. Available online: https://www.ncbi.nlm.nih. gov/gene/8831 (accessed on 1 April 2021).

18. Jeyabalan, N.; Clement, J.P. SYNGAP1: Mind the gap. Front. Cell. Neurosci. 2016, 10, 1-16. [CrossRef] [PubMed]

19. Online Mendelian Inheritance in Man, OMIM®. Johns Hopkins University, Baltimore, M.D. MENTAL RETARDATION, AUTOSOMAL DOMINANT 5; MRD5. Number: \# 612621. Available online: https:/ /www.omim.org/entry/612621 (accessed on 1 April 2021).

20. Matricardi, S. Orphanet Encyclopedia SYNGAP1-Related Developmental and Epileptic Encephalopathy. Available online: https://www.orpha.net/consor/cgi-bin/Disease_Search.php?lng=EN\&data_id=28070\&Disease_Disease_Search_ diseaseGroup=SYNGAP1\&Disease_Disease_Search_diseaseType=Gen\&Disease (accessed on 1 April 2021).

21. Mignot, C.; von Stülpnagel, C.; Nava, C.; Ville, D.; Sanlaville, D.; Lesca, G.; Rastetter, A.; Gachet, B.; Marie, Y.; Korenke, G.C.; et al. Genetic and neurodevelopmental spectrum of SYNGAP1-associated intellectual disability and epilepsy. J. Med. Genet. 2016, 53, 511-522. [CrossRef]

22. Berryer, M.H.; Hamdan, F.F.; Klitten, L.L.; Møller, R.S.; Carmant, L.; Schwartzentruber, J.; Patry, L.; Dobrzeniecka, S.; Rochefort, D.; Neugnot-Cerioli, M.; et al. Mutations in SYNGAP1 Cause Intellectual Disability, Autism, and a Specific Form of Epilepsy by Inducing Haploinsufficiency. Hum. Mutat. 2013, 34, 385-394. [CrossRef]

23. Vlaskamp, D.R.M.; Shaw, B.J.; Burgess, R.; Mei, D.; Montomoli, M.; Xie, H.; Myers, C.T.; Bennett, M.F.; Xiangwei, W.; Williams, D.; et al. SYNGAP1 encephalopathy: A distinctive generalized developmental and epileptic encephalopathy. Neurology 2019, 92, E96-E107. [CrossRef]

24. Lo Barco, T.; Kaminska, A.; Solazzi, R.; Cancés, C.; Barcia, G.; Chemaly, N.; Fontana, E.; Desguerre, I.; Canafoglia, L.; Hachon Le Camus, C.; et al. Syngap1-Dee: A visual sensitive epilepsy. Clin. Neurophysiol. 2021, 132, 841-850. [CrossRef]

25. Kuchenbuch, M.; D'Onofrio, G.; Chemaly, N.; Barcia, G.; Teng, T.; Nabbout, R. Add-on cannabidiol significantly decreases seizures in 3 patients with SYNGAP1 developmental and epileptic encephalopathy. Epilepsia Open 2020, 5, 496-500. [CrossRef]

26. Okazaki, T.; Saito, Y.; Hiraiwa, R.; Saitoh, S.; Kai, M.; Adachi, K.; Nishimura, Y.; Nanba, E.; Maegaki, Y. Pharmacoresistant epileptic eyelid twitching in a child with a mutation in SYNGAP1. Epileptic Disord. 2017, 19, 339-344. [CrossRef]

27. Redin, C.; Gérard, B.; Lauer, J.; Herenger, Y.; Muller, J.; Quartier, A.; Masurel-Paulet, A.; Willems, M.; Lesca, G.; El-Chehadeh, S.; et al. Efficient strategy for the molecular diagnosis of intellectual disability using targeted high-throughput sequencing. J. Med. Genet. 2014, 51, 724-736. [CrossRef]

28. von Stülpnagel, C.; Hartlieb, T.; Borggräfe, I.; Coppola, A.; Gennaro, E.; Eschermann, K.; Kiwull, L.; Kluger, F.; Krois, I.; Møller, R.S.; et al. Chewing induced reflex seizures ("eating epilepsy") and eye closure sensitivity as a common feature in pediatric patients with SYNGAP1 mutations: Review of literature and report of 8 cases. Seizure 2019, 65, 131-137. [CrossRef] [PubMed]

29. Carvill, G.L.; Heavin, S.B.; Yendle, S.C.; McMahon, J.M.; O’Roak, B.J.; Cook, J.; Khan, A.; Dorschner, M.O.; Weaver, M.; Calvert, S.; et al. Targeted resequencing in epileptic encephalopathies identifies de novo mutations in CHD2 and SYNGAP1. Nat. Genet. 2013, 45, 825-830. [CrossRef]

30. Parrini, E.; Marini, C.; Mei, D.; Galuppi, A.; Cellini, E.; Chiti, L.; Rutigliano, D.; Bianchini, C.; Virdò, S.; De, D.; et al. Diagnostic Targeted Resequencing in 349 Patients with Drug-Resistant Pediatric Epilepsies Identifies Causative Mutations in 30 Different Genes. Hum. Mutat. 2017, 38, 216-225. [CrossRef] [PubMed]

31. Deciphering Developmental Disorders Study. Prevalence and architecture of de novo mutations in developmental disorders. Nature 2017, 542, 433-438. [CrossRef] [PubMed]

32. Online Mendelian Inheritance in Man, OMIM®. Johns Hopkins University, Baltimore, M.D. NEURITE EXTENSION AND MIGRATION FACTOR; NEXMIF. Number: * 300524. Available online: https: / / www.omim.org/entry/300524 (accessed on 1 April 2021).

33. Cantagrel, V.; Haddad, M.R.; Ciofi, P.; Andrieu, D.; Lossi, A.M.; van Maldergem, L.; Roux, J.C.; Villard, L. Spatiotemporal expression in mouse brain of Kiaa2022, a gene disrupted in two patients with severe mental retardation. Gene Expr. Patterns 2009, 9, 423-429. [CrossRef] [PubMed]

34. Ishikawa, T.; Miyata, S.; Koyama, Y.; Yoshikawa, K.; Hattori, T.; Kumamoto, N.; Shingaki, K.; Katayama, T.; Tohyama, M. Transient expression of Xpn, an XLMR protein related to neurite extension, during brain development and participation in neurite outgrowth. Neuroscience 2012, 214, 181-191. [CrossRef] [PubMed]

35. Magome, T.; Hattori, T.; Taniguchi, M.; Ishikawa, T.; Miyata, S.; Yamada, K.; Takamura, H.; Matsuzaki, S.; Ito, A.; Tohyama, M.; et al. XLMR protein related to neurite extension (Xpn/KIAA2022) regulates cell-cell and cell-matrix adhesion and migration. Neurochem. Int. 2013, 63, 561-569. [CrossRef] [PubMed]

36. Online Mendelian Inheritance in Man, OMIM®. Johns Hopkins University, Baltimore, M.D. MENTAL RETARDATION, XLINKED 98; MRX98. Number: \# 300912. Available online: https://www.omim.org/entry/300912 (accessed on 1 April 2021). 
37. Lorenzo, M.; Stolte-Dijkstra, I.; van Rheenen, P.; Smith, R.G.; Scheers, T.; Walia, J.S. Clinical spectrum of KIAA2022 pathogenic variants in males: Case report of two boys with KIAA2022 pathogenic variants and review of the literature. Am. J. Med. Genet. Part A 2018, 176, 1455-1462. [CrossRef]

38. de Lange, I.M.; Helbig, K.L.; Weckhuysen, S.; Møller, R.S.; Velinov, M.; Dolzhanskaya, N.; Marsh, E.; Helbig, I.; Devinsky, O.; Tang, S.; et al. De novo mutations of KIAA2022 in females cause intellectual disability and intractable epilepsy. J. Med. Genet. 2016, 53, 850-858. [CrossRef]

39. Webster, R.; Cho, M.T.; Retterer, K.; Millan, F.; Nowak, C.; Douglas, J.; Ahmad, A.; Raymond, G.V.; Johnson, M.R.; Pujol, A.; et al. De novo loss of function mutations in KIAA2022 are associated with epilepsy and neurodevelopmental delay in females. Clin. Genet. 2017, 91, 756-763. [CrossRef]

40. Borlot, F.; Regan, B.M.; Bassett, A.S.; Stavropoulos, D.J.; Andrade, D.M. Prevalence of pathogenic copy number variation in adults with pediatric-onset epilepsy and intellectual disability. JAMA Neurol. 2017, 74, 1301-1311. [CrossRef] [PubMed]

41. Myers, C.T.; Hollingsworth, G.; Muir, A.M.; Schneider, A.L.; Thuesmunn, Z.; Knupp, A.; King, C.; Lacroix, A.; Mehaffey, M.G.; Berkovic, S.F.; et al. Parental Mosaicism in "De Novo" Epileptic Encephalopathies. N. Engl. J. Med. 2018, 378, 1646-1648. [CrossRef] [PubMed]

42. Stamberger, H.; Hammer, T.B.; Gardella, E.; Vlaskamp, D.R.M.; Bertelsen, B.; Mandelstam, S.; de Lange, I.; Zhang, J.; Myers, C.T.; Fenger, C.; et al. NEXMIF encephalopathy: An X-linked disorder with male and female phenotypic patterns. Genet. Med. 2021, 23, 363-373. [CrossRef] [PubMed]

43. Wu, D.; Ji, C.; Chen, Z.; Wang, K. Novel NEXMIF gene pathogenic variant in a female patient with refractory epilepsy and intellectual disability. Am. J. Med. Genet. Part A 2020, 182, 2765-2772. [CrossRef] [PubMed]

44. Viravan, S.; Go, C.; Ochi, A.; Akiyama, T.; Carter Snead, O.; Otsubo, H. Jeavons syndrome existing as occipital cortex initiating generalized epilepsy. Epilepsia 2011, 52, 1273-1279. [CrossRef]

45. Online Mendelian Inheritance in Man, OMIM ${ }^{\circledR}$. Johns Hopkins University, Baltimore, M.D. RAR-RELATED ORPHAN RECEPTOR B; RORB. Number: * 601972. Available online: https:/ / www.omim.org/entry/601972 (accessed on 1 April 2021).

46. Liu, H.; Aramaki, M.; Fu, Y.; Forrest, D. Retinoid-Related Orphan Receptor $\beta$ and Transcriptional Control of Neuronal Differentiation, 1st ed.; Elsevier Inc.: New York, NY, USA, 2017; Volume 125.

47. Online Mendelian Inheritance in Man, OMIM®. Johns Hopkins University, Baltimore, M.D. EPILEPSY, IDIOPATHIC GENERALIZED, SUSCEPTIBILITY TO, 15; EIG15. Number: \# 618357. Available online: https:/ /www.omim.org/entry/618357 (accessed on 1 April 2021).

48. Bartnik, M.; Szczepanik, E.; Derwińska, K.; Wiśniowiecka-Kowalnik, B.; Gambin, T.; Sykulski, M.; Ziemkiewicz, K.; Keogonekdzior, M.; Gos, M.; Hoffman-Zacharska, D.; et al. Application of array comparative genomic hybridization in 102 patients with epilepsy and additional neurodevelopmental disorders. Am. J. Med. Genet. Part B Neuropsychiatr. Genet. 2012, 159, 760-771. [CrossRef]

49. Rudolf, G.; Lesca, G.; Mehrjouy, M.M.; Labalme, A.; Salmi, M.; Bache, I.; Bruneau, N.; Pendziwiat, M.; Fluss, J.; De Bellescize, J.; et al. Loss of function of the retinoid-related nuclear receptor (RORB) gene and epilepsy. Eur. J. Hum. Genet. 2016, 24, 1761-1770. [CrossRef]

50. Sadleir, L.G.; de Valles-Ibáñez, G.; King, C.; Coleman, M.; Mossman, S.; Paterson, S.; Nguyen, J.; Berkovic, S.F.; Mullen, S.; Bahlo, M.; et al. Inherited RORB pathogenic variants: Overlap of photosensitive genetic generalized and occipital lobe epilepsy. Epilepsia 2020, 61, e23-e29. [CrossRef]

51. Online Mendelian Inheritance in Man, OMIM®. Johns Hopkins University, Baltimore, M.D. CHROMODOMAIN HELICASE DNA-BINDING PROTEIN 2; CHD2. Number: * 602119. Available online: https://www.omim.org/entry/602119 (accessed on 1 April 2021).

52. Wilson, M.M.; Henshall, D.C.; Byrne, S.M.; Brennan, G.P. Chd2-related cns pathologies. Int. J. Mol. Sci. 2021, 22, 588. [CrossRef] [PubMed]

53. Online Mendelian Inheritance in Man, OMIM®. Johns Hopkins University, Baltimore, M.D. EPILEPTIC ENCEPHALOPATHY, CHILDHOOD-ONSET; EEOC. Number: \# 615369. Available online: https:/ /www.omim.org/entry/615369 (accessed on 1 April 2021).

54. Helbig, I. Orphanet Encyclopedia Myoclonic-Astatic Epilepsy. Available online: https://www.orpha.net/consor/cgibin/Disease_Search.php?Ing=EN\&data_id=891\&Disease_Disease_Search_diseaseGroup=CHD2\&Disease_Disease_Search_ diseaseType=Gen\&Enfermedad(es) (accessed on 1 April 2021).

55. Galizia, E.C.; Myers, C.T.; Leu, C.; De Kovel, C.G.F.; Afrikanova, T.; Cordero-Maldonado, M.L.; Martins, T.G.; Jacmin, M.; Drury, S.; Chinthapalli, V.K.; et al. CHD2 variants are a risk factor for photosensitivity in epilepsy. Brain 2015, 138, 1198-1207. [CrossRef]

56. Thomas, R.H.; Zhang, L.M.; Carvill, G.L.; Archer, J.S.; Heavin, S.B.; Mandelstam, S.A.; Craiu, D.; Berkovic, S.F.; Gill, D.S.; Mefford, H.C.; et al. CHD2 myoclonic encephalopathy is frequently associated with self-induced seizures. Neurology 2015, 84, 951-958. [CrossRef] [PubMed]

57. Mullen, S.A.; Carvill, G.L.; Bellows, S.; Bayly, M.A.; Berkovic, S.F.; Dibbens, L.M.; Scheffer, I.E.; Mefford, H.C. Copy number variants are frequent in genetic generalized epilepsy with intellectual disability. Neurology 2013, 81, 1507-1514. [CrossRef] [PubMed] 
58. Online Mendelian Inheritance in Man, OMIM®. Johns Hopkins University, Baltimore, M.D. SOLUTE CARRIER FAMILY 2 (FACILITATED GLUCOSE TRANSPORTER), MEMBER 1; SLC2A1. Number: * 138140. Available online: https://www.omim. org/entry/138140 (accessed on 1 April 2021).

59. Online Mendelian Inheritance in Man, OMIM®. Johns Hopkins University, Baltimore, M.D. GLUT1 DEFICIENCY SYNDROME 1; GLUT1DS1. Number: \# 606777. Available online: https:/ / omim.org/entry/606777 (accessed on 1 April 2021).

60. De Lonlay, P.P. Orphanet Encyclopedia Classic Glucose Transporter Type 1 Deficiency Syndrome. Available online: https: / / www.orpha.net/consor / cgi-bin/Disease_Search.php?lng=EN\&data_id=10999\&Disease_Disease_Search_diseaseGroup= GLUt1\&Disease_Disease_Search_diseaseType=Pat\&Disease (accessed on 1 April 2021).

61. Gökben, S.; Yilmaz, S.; Klepper, J.; Serdaroğlu, G.; Tekgül, H. Video/EEG recording of myoclonic absences in GLUT1 deficiency syndrome with a hot-spot R126C mutation in the SLC2A1 gene. Epilepsy Behav. 2011, 21, 200-202. [CrossRef] [PubMed]

62. Diomedi, M.; Gan-Or, Z.; Placidi, F.; Dion, P.A.; Szuto, A.; Bengala, M.; Rouleau, G.A.; Gigli, G.L. A 23 years follow-up study identifies GLUT1 deficiency syndrome initially diagnosed as complicated hereditary spastic paraplegia. Eur. J. Med. Genet. 2016, 59, 564-568. [CrossRef]

63. Altıokka-Uzun, G.; Özdemir, Ö.; Uğur-İşeri, S.; Bebek, N.; Gürses, C.; Özbek, U.; Baykan, B. Investigation of SLC2A1 gene variants in genetic generalized epilepsy patients with eyelid myoclonia. Epileptic Disord. 2018, 20, 396-400. [CrossRef]

64. Online Mendelian Inheritance in Man, OMIM®. Johns Hopkins University, Baltimore, M.D. POTASSIUM CHANNEL, VOLTAGEGATED, SHAB-RELATED SUBFAMILY, MEMBER 1; KCNB1. Number: * 600397. Available online: https://www.omim.org/ entry/600397 (accessed on 1 April 2021).

65. Online Mendelian Inheritance in Man, OMIM®. Johns Hopkins University, Baltimore, M.D. DEVELOPMENTAL AND EPILEPTIC ENCEPHALOPATHY 26; DEE26. Number: \# 616056. Available online: https: / / www.omim.org/entry/616056 (accessed on 1 April 2021).

66. Marini, C.; Romoli, M.; Parrini, E.; Costa, C.; Mei, D.; Mari, F.; Parmeggiani, L.; Procopio, E.; Metitieri, T.; Cellini, E.; et al. Clinical features and outcome of 6 new patients carrying de novo KCNB1 gene mutations. Neurol. Genet. 2017, 3, e206. [CrossRef]

67. Saitsu, H.; Akita, T.; Tohyama, J.; Goldberg-Stern, H.; Kobayashi, Y.; Cohen, R.; Kato, M.; Ohba, C.; Miyatake, S.; Tsurusaki, Y.; et al. De novo KCNB1 mutations in infantile epilepsy inhibit repetitive neuronal firing. Sci. Rep. 2015, 5, 1-14. [CrossRef]

68. Minardi, R.; Licchetta, L.; Baroni, M.C.; Pippucci, T.; Stipa, C.; Mostacci, B.; Severi, G.; Toni, F.; Bergonzini, L.; Carelli, V.; et al. Whole-exome sequencing in adult patients with developmental and epileptic encephalopathy: It is never too late. Clin. Genet. 2020, 98, 477-485. [CrossRef]

69. Online Mendelian Inheritance in Man, OMIM®. Johns Hopkins University, Baltimore, M.D. N-ALPHA-ACETYLTRANSFERASE 10, NatA CATALYTIC SUBUNIT; NAA10. Number: * 300013. Available online: https://www.omim.org/entry/300013 (accessed on 1 April 2021).

70. Online Mendelian Inheritance in Man, OMIM®. Johns Hopkins University, Baltimore, M.D. OGDEN SYNDROME. Number: \# 300855. Available online: https:/ /www.omim.org/entry/300855 (accessed on 1 April 2021).

71. Saunier, C.; Støve, S.I.; Popp, B.; Gérard, B.; Blenski, M.; AhMew, N.; de Bie, C.; Goldenberg, P.; Isidor, B.; Keren, B.; et al. Expanding the Phenotype Associated with NAA10-Related N-Terminal Acetylation Deficiency. Hum. Mutat. 2016, 37, 755-764. [CrossRef] [PubMed]

72. Popp, B.; Støve, S.I.; Endele, S.; Myklebust, L.M.; Hoyer, J.; Sticht, H.; Azzarello-Burri, S.; Rauch, A.; Arnesen, T.; Reis, A. De novo missense mutations in the NAA10 gene cause severe non-syndromic developmental delay in males and females. Eur. J. Hum. Genet. 2015, 23, 602-609. [CrossRef]

73. Cantagrel, V.; Lossi, A.M.; Boulanger, S.; Depetris, D.; Mattei, M.G.; Gecz, J.; Schwartz, C.E.; Van Maldergem, L.; Villard, L. Disruption of a new $X$ linked gene highly expressed in brain in a family with two mentally retarded males. J. Med. Genet. 2004, 41, 736-742. [CrossRef] [PubMed]

74. Xiuli, G.; Meiyu, G.; Guanhua, D. Glucose transporter 1, distribution in the brain and in neural disorders: Its relationship with transport of neuroactive drugs through the blood-brain barrier. Biochem. Genet. 2005, 43, 175-187. [CrossRef] [PubMed]

75. Warde-Farley, D.; Donaldson, S.L.; Comes, O.; Zuberi, K.; Badrawi, R.; Chao, P.; Franz, M.; Grouios, C.; Kazi, F.; Lopes, C.T.; et al. The GeneMANIA prediction server: Biological network integration for gene prioritization and predicting gene function. Nucleic Acids Res. 2010, 38, 214-220. [CrossRef] [PubMed]

76. Clement, J.P.; Aceti, M.; Creson, T.K.; Ozkan, E.D.; Shi, Y.; Reish, N.J.; Almonte, A.G.; Miller, B.H.; Wiltgen, B.J.; Miller, C.A.; et al. Pathogenic SYNGAP1 mutations impair cognitive development by disrupting maturation of dendritic spine synapses. Cell 2012, 151, 709-723. [CrossRef]

77. Ozkan, E.D.; Creson, T.K.; Kramár, E.A.; Rojas, C.; Seese, R.R.; Babyan, A.H.; Shi, Y.; Lucero, R.; Xu, X.; Noebels, J.L.; et al. Reduced cognition in Syngap1 mutants is caused by isolated damage within developing forebrain excitatory neurons. Neuron 2014, 82, 1317-1333. [CrossRef]

78. Creson, T.K.; Rojas, C.; Hwaun, E.; Vaissiere, T.; Kilinc, M.; Jimenez-Gomez, A.; Holder, J.L.; Tang, J.; Colgin, L.L.; Miller, C.A.; et al. Re-expression of SynGAP protein in adulthood improves translatable measures of brain function and behavior. Elife 2019, 8 , e46752. [CrossRef] [PubMed]

79. Sullivan, B.J.; Ammanuel, S.; Kipnis, P.A.; Araki, Y.; Huganir, R.L.; Kadam, S.D. Low-Dose Perampanel Rescues Cortical Gamma Dysregulation Associated With Parvalbumin Interneuron GluA2 Upregulation in Epileptic Syngap1 +/ - Mice. Biol Psychiatry 2020, 87, 829-842. [CrossRef] [PubMed] 
80. Gilbert, J.; O'Connor, M.; Templet, S.; Moghaddam, M.; Di Via Ioschpe, A.; Sinclair, A.; Zhu, L.Q.; Xu, W.; Man, H.Y. NExMIF/Kidlia knock-out mouse demonstrates autism-like behaviors, memory deficits, and impairments in synapse formation and function. J. Neurosci. 2020, 40, 237-254. [CrossRef] [PubMed]

81. Zlotogora, J. Germ line mosaicism. Hum. Genet. 1998, 102, 381-386. [CrossRef] [PubMed] 